\title{
IN VIVO AND IN VITRO DEGRADATION COMPARISON OF PURE MG, MG-10GD AND MG-2AG: A SHORT TERM STUDY
}

\author{
I. Marco ${ }^{1, \S, *}$, A. Myrissa ${ }^{2,}$, E. Martinelli², F. Feyerabend ${ }^{3}$, R. Willumeit-Römer ${ }^{3}$, A.M. Weinberg ${ }^{2}$ \\ and $\mathrm{O}$. Van der Biest ${ }^{1}$ \\ ${ }^{1}$ Department of Materials Engineering, KU Leuven, Leuven, Belgium \\ ${ }^{2}$ Department of Orthopaedic Surgery, Medical University Graz, Graz, Austria \\ ${ }^{3}$ Institute of Materials Research, Helmholtz-Zentrum Geesthacht, Geesthacht, Germany \\ $\S$ These authors contributed equally
}

\begin{abstract}
The purpose of this study was to compare short term in vitro and in vivo biodegradation studies with low purity Mg (> $99.94 \%$ ), Mg-10Gd and Mg-2Ag designed for biodegradable implant applications. Three in vitro testing conditions were applied, using (i) phosphate buffered saline (PBS), (ii) Hank's balanced salt solution (HBSS) and (iii) Dulbecco's modified eagle medium (DMEM) in $5 \% \mathrm{CO}_{2}$ under sterile conditions. Gas evolution and mass loss (ML) were assessed, as well as the degradation layer, by elemental mapping and scanning electron microscopy (SEM). In vivo, implantations were performed on male Sprague-Dawley rats evaluating both, gas cavity volume and implant volume reduction by micro-computed tomography ( $\mu \mathrm{CT}), 7 \mathrm{~d}$ after implantation. Samples were produced by casting, solution heat treatment and extrusion in disc and pin shape for the in vitro and in vivo experiments, respectively. Results showed that when the processing of the $\mathrm{Mg}$ sample varied, differences were found not only in the alloy impurity content and the grain size, but also in the corrosion behaviour. An increase of $\mathrm{Fe}$ and $\mathrm{Ni}$ or a large grain size seemed to play a major role in the degradation process, while the influence of alloying elements, such as Gd and Ag, played a secondary role. Results also indicated that cell culture conditions induced degradation rates and degradation layer elemental composition comparable to in vivo conditions. These in vitro and in vivo degradation layers consisted of $\mathrm{Mg}$ hydroxide, $\mathrm{Mg}$-Ca carbonate and Ca phosphate.
\end{abstract}

Keywords: Magnesium alloys, biodegradation, in vitro, in vivo, degradation.

\author{
*Address for correspondence: \\ Iñigo Marco \\ Department of Materials Engineering, KU Leuven \\ Kasteelpark Arenberg 44-bus 2450 \\ 3001 Leuven, Belgium
}

Telephone: +32 16373555

Fax: +3216321990

Email: inigo.marco88@gmail.com

\section{Introduction}

Magnesium $(\mathrm{Mg})$ is a promising material to be used during bone healing as biodegradable orthopaedic implant for fracture stabilisation. As a consequence of its degradability, the second surgery for implant removal can be avoided. Furthermore, $\mathrm{Mg}$ has similar density and mechanical properties compared to cortical bone, and has non-toxic and biocompatible properties as well (Kirkland et al., 2010; Staiger et al., 2006; Witte et al., 2005). Complete bioresorption of $\mathrm{Mg}$ implants in vivo has been proven depending on the Mg-based material, keeping sufficient mechanical integrity during osteogenesis (Kraus et al., 2012). Therefore, different applications can be aimed at by selecting the Mg alloy. Examples are bone fixation screws, intramedullary cavity fixation rod, cardiovascular stents, wound closing devices and scaffolds for tissue engineering.

However, biodegradation of pure $\mathrm{Mg}$ and $\mathrm{Mg}$-alloys is a complex process, hard to predict. It is proven that ultrahigh-purity $\mathrm{Mg}$ degrades very slowly in vitro and in vivo with a degradation rate (DR) of $10 \mu \mathrm{m} /$ year (Hofstetter et al., 2015b). This shows the large influence of impurities on the biodegradation behaviour. $\mathrm{Mg}$ degradation is highly influenced not only by impurities (Hanawalt et al., 1942; Hofstetter et al., 2015a; Hofstetter et al., 2015b; Lee et al., 2009; Liu et al., 2009; Reichek et al., 1985; Yang et $a l ., 2015)$, but also by alloys addition and grain size (Liu et al., 2015). Furthermore, the degradation conditions and the performance of the formed surface layer have also an impact (Walker et al., 2012).

Although some attempts have been made to correlate in vitro and in vivo results (Li et al., 2014; Li et al., 2012; Shadanbaz et al., 2014; Witte et al., 2006), in general the comparison between different methods is poor (MartinezSanchez et al., 2015). In some cases the immersion testing conditions apply different electrolytes, buffering and solution volume to sample surface ratio (V/S) and, as a result, the comparison with in vivo experiments is hardly possible ( $\mathrm{Li}$ et al., 2014). Hence, there is a need for a standardised in vitro testing method, which can be compared to in vivo conditions (Martinez-Sanchez et al., 2015; Zhang et al., 2013). For this reason we have selected three electrolytes, commonly used in literature, for an in vitro study: phosphate buffered saline (PBS) (Ahmadkhaniha et al., 2016; Alvarez-Lopez et al., 2010; Schille et al., 2011; Trinidad et al., 2013), Hank's balanced salt solution or Hank's solution (HBSS) (Wang et al., 2008; 
Zainal Abidin et al., 2011) and a cell culture basal medium, Dulbecco's modified eagle medium (DMEM) (Feyerabend et al., 2012; Marco et al., 2016; Tie et al., 2010; Tie et al., 2013; Yang et al., 2012), which is similar to plasma and whole blood (Feyerabend et al., 2015). While PBS uses a phosphate ion based buffering system and DMEM contains a carbonate based system, HBSS contains a smaller amount of both buffering systems. Hofstetter et al. applied a setup with comparable in vitro and in vivo results, which consisted of one single stirred bath with the addition of $\mathrm{CO}_{2}$ (Hofstetter et al., 2015b). In the present work, cell culture conditions are applied with DMEM in a similar setup to that applied by Hofstetter et al. (2015b). The same testing conditions were also investigated in our previous work (Marco et al., 2016).

Since the required resorption rate for $\mathrm{Mg}$-alloys depends on the application, different alloying elements, which can tune this rate, were selected. In the present study, the selected elements were silver (Ag) and gadolinium (Gd). Ag is considered as an impurity with a low tolerance limit, which accelerates the degradation process (Friedrich and Mordike, 2006). Moreover, Ag is known for its antibacterial properties (Tie et al., 2013), also shown by $\mathrm{Mg}$ (Robinson et al., 2010; Zhu et al., 2014). Mg-Gd is reported as a slowly degrading alloy. Gd can form intermetallic compounds with impurities less harmful to the corrosion resistance (Mercer and Hillis, 1992) and it also improves the mechanical properties of Mg-Gd binary alloys (Hort et al., 2010; Kubasek and Vojtech, 2013).

We analysed different $\mathrm{Mg}$ alloys, produced in disc and pin shape, under in vitro and in vivo conditions respectively, comparing DRs and surface layers formed after $7 \mathrm{~d}$. In this analysis, impurity level and grain size were of great importance. Difficulties in distinguishing bone from the degradation layer after in vivo experiments by microcomputed tomography $(\mu \mathrm{CT})$ have been recently reported (Galli et al., 2015). These difficulties are related to the resolution of the tomographic method and the equipment used, and to differences in X-ray absorption between bone and the degradation layer. Therefore, this work also analyses the degradation layer trying to clarify the differences between bone and these layers and comparing the layers formed during in vivo and in vitro experiments.

\section{Materials and Methods}

\section{Material preparation}

The raw materials used for the $\mathrm{Mg}$ alloy production were magnesium (99.99 \%, Xinxiang Jiuli Magnesium co. Ltd, Beijing, China), gadolinium (99.95 \%, Grirem Adv. Mater. Co. Ltd., Beijing, China) and silver (99.99\%, ESG Edelmetall-Handel GmbH \& Co. KG, Rheinstetten, Germany). All the alloys underwent thermomechanical processing steps at elevated temperatures appropriate for each alloy in order to homogenise their composition and microstructure. Ingots were cast in a permanent mould casting at $680-720{ }^{\circ} \mathrm{C}$ in protective atmosphere $\left(\mathrm{Ar}+2 \% \mathrm{SF}_{6}\right)$ and heat treated for $6 \mathrm{~h}$ at $420-430{ }^{\circ} \mathrm{C}$ for $\mathrm{Mg}-2 \mathrm{Ag}$ and $500-550{ }^{\circ} \mathrm{C}$ for $\mathrm{Mg}-10 \mathrm{Gd}$. Then $\mathrm{Mg}-10 \mathrm{Gd}$ and $\mathrm{Mg}-2 \mathrm{Ag}$ samples were extruded at $370-450{ }^{\circ} \mathrm{C}$ from a diameter of $30 \mathrm{~mm}$ to a diameter $12 \mathrm{~mm}$ with a speed of 2.5-4.5 $\mathrm{mm} / \mathrm{sec}$, while pure $\mathrm{Mg}$ was reduced in diameter from $110 \mathrm{~mm}$ to $12 \mathrm{~mm}$ at $300{ }^{\circ} \mathrm{C}$ at $0.7 \mathrm{~mm} / \mathrm{s}$ without previous heat treatment. Finally, the wires were cut into discs of $10 \mathrm{~mm}$ diameter and $1.5 \mathrm{~mm}$ thickness, with a mass of approximately $180 \mathrm{mg}$ each.

For the in vivo experiments, the same materials were used in pin shape and in order to achieve this, the extrusion was done to a final rod diameter of $6 \mathrm{~mm}$. The extruded pure $\mathrm{Mg}(99.956 \%)$ and $\mathrm{Mg}-10 \mathrm{Gd}$ rods (diameter $=6 \mathrm{~mm})$ were further reduced to $1.6 \mathrm{~mm}$ diameter by turning (Ernst Wittner GmbH, Vienna, Austria). The Mg-2Ag extruded rods were drawn to wires using hardened steel drawplates. The wires were annealed at $300{ }^{\circ} \mathrm{C}$ for $45 \mathrm{~min}$ in the furnace applying 1 to 3 wire drawing steps and then they were drawn to a diameter of $1.6 \mathrm{~mm}$. After production, the samples were sterilised by $\gamma$-irradiation at $29.2 \mathrm{kGy}(\mathrm{BBF}$ $\mathrm{GmbH}$, Stuttgart, Germany) and afterwards, no surface preparation was applied.

Chemical composition and impurity content were determined by inductively coupled plasma optical emission spectroscopy (ICP-OES, Varian 720 ES, East Lyme, CT, USA). For grain size analysis, samples were embedded in epoxy resin and the surfaces prepared by grinding with $\mathrm{SiC}$ sandpaper of 1000-grits to 4000-grits (Matador 991A, Remscheid, Germany), and finally by polishing with diamond suspension of $3 \mu \mathrm{m}$ (Kemet, Maidstone,
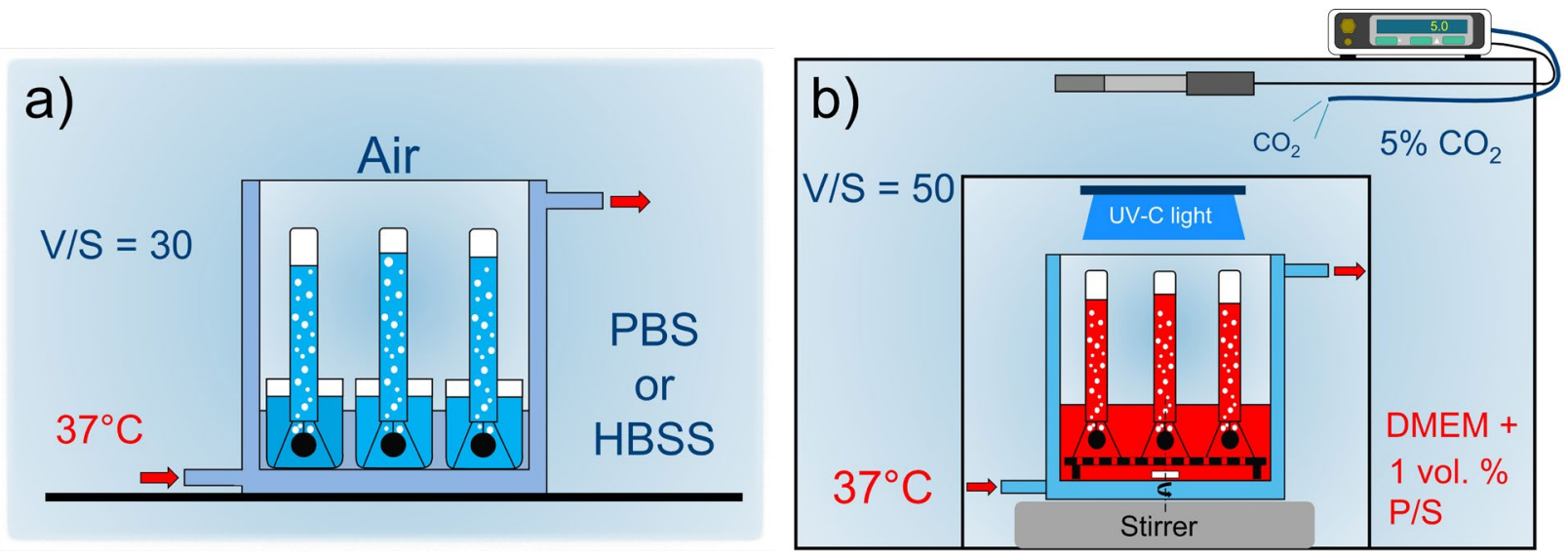

Fig. 1. Immersion test setups. (a) PBS and HBSS and (b) DMEM and $5 \% \mathrm{CO}_{2}$ under sterile conditions. In DMEM, one single bath is stirred in order to assure the same $\mathrm{pH}$ and sterile conditions to the entire bath; in PBS and HBSS, the analysis is performed individually, since medium contamination does not occur. 
Table 1. Ionic composition of different media used for $\mathrm{Mg}$ degradation tests in $\mathrm{mmol} / \mathrm{L}$.

\begin{tabular}{|c|c|c|c|c|c|c|c|c|c|c|c|c|c|}
\hline & $\mathrm{Na}^{+}$ & $\mathbf{K}^{+}$ & $\mathrm{Ca}^{2+}$ & $\mathbf{M g}^{2+}$ & $\mathrm{Cl}^{-}$ & $\mathrm{HCO}_{3}^{-}$ & $\mathrm{H}_{2} \mathrm{PO}_{4}^{-}$ & $\mathrm{HPO}_{4}{ }^{2-}$ & $\mathrm{SO}_{4}{ }^{2-}$ & $\begin{array}{c}\text { Amino } \\
\text { acids }\end{array}$ & D-Glucose & Vitamins & $\begin{array}{c}\text { Phenol } \\
\text { red }\end{array}$ \\
\hline PBS & 154.1 & 4.1 & - & - & 140.6 & - & 1.5 & 8.1 & - & - & - & - & - \\
\hline HBSS & 142.8 & 5.8 & - & - & 143.3 & 4.2 & 0.4 & 0.3 & - & - & 5.6 & - & - \\
\hline DMEM & 155.3 & 5.3 & 1.8 & 0.8 & 115.7 & 44.1 & - & 0.9 & 0.8 & 10.6 & 25 & 0.15 & 0.04 \\
\hline
\end{tabular}

England). Then, pure Mg- and Mg-10Gd-containing alloys were etched in picric acid solution $(6 \mathrm{~g}$ of picric acid, $5 \mathrm{~mL}$ of acetic acid, $10 \mathrm{~mL}$ of $\mathrm{H}_{2} \mathrm{O}$ and $100 \mathrm{~mL}$ of ethanol) for $2 \mathrm{~s}$, while the etching of $\mathrm{Mg}-2 \mathrm{Ag}$ was done as quickly as manually possible (less than $1 \mathrm{~s}$ ). Grain size was determined by optical microscopy and linear intercept method with ImageJ software (version $1.47 \mathrm{v}$, Wayne Rasband, Bethesda, MD, USA). Density was measured with Archimedes's method comparing the mass of the samples in air and in ethanol at $25^{\circ} \mathrm{C}$.

\section{In vitro degradation testing}

For the in vitro degradation study, two different setup configurations were applied during 4 to $7 \mathrm{~d}$ (Fig. 1). On the one hand, PBS (4417, Sigma Aldrich, St. Louis, MO, USA) and HBSS (14175, Life Technologies, Grand Island, NY, USA) in atmosphere air at $37 \pm 0.5^{\circ} \mathrm{C}$ were used as non-physiological testing conditions (Fig. 1a). PBS and HBSS are electrolytes commonly applied in $\mathrm{Mg}$ degradation experiments as they have a strong buffering capacity, because they contain phosphates and, in HBSS case, also carbonates. On the other hand, testing under near physiological conditions or cell culture conditions (Fig. 1b) was performed as in our previous work (Marco et al., 2016). This consisted of immersion in DMEM Glutamax-I (61965, Invitrogen, Paisley, UK) in air with $5 \% \mathrm{CO}_{2}$ at $37 \pm 0.5{ }^{\circ} \mathrm{C}$ with the same stirred bath of $600 \mathrm{~mL}$ under sterile conditions. In literature, it is recommended to apply one single bath for different physiological electrolyte concentrations (Hofstetter et al., 2015b; Schinhammer et al., 2013; Zainal Abidin et al., 2013). However, for testing in PBS and HBSS each sample was immersed in one single bath to allow single $\mathrm{pH}$ measurements. In both configurations, experiments were performed simultaneously with six samples for each alloy. Table 1 shows the composition of the media used for the in vitro study.

The $\mathrm{V} / \mathrm{S}$ ratio applied in this study was $30 \mathrm{~mL} / \mathrm{cm}^{2}$ for PBS and HBSS conditions and $50 \mathrm{~mL} / \mathrm{cm}^{2}$ for immersion in DMEM. As Kirkland et al. stated, at V/S ratios higher than 30 the $\mathrm{V} / \mathrm{S}$ ratio has no longer a statistically significant influence on the DR (Kirkland et al., 2012). The duration of the test depended on the limit of $\mathrm{H}_{2}$ collection, which was defined by the eudiometer capacity of $35 \mathrm{~mL}$, and the risk of DMEM contamination. As in our previous work, an empty control position test was performed without any sample under physiological conditions in order to evaluate the gas accumulation due to artefacts created by the stirring and the $\mathrm{CO}_{2}$ in solution (Marco et al., 2016).

The surface finishing of the discs was done firstly by grinding all the surfaces with $\mathrm{SiC}$ sandpaper of 1000-grits to 4000-grits (Matador 991A, Remscheid, Germany), and finally by polishing with diamond suspension of $3 \mu \mathrm{m}$ (Kemet, Maidstone, England). The DRs were determined by mass loss (ML) measurements. Samples were first removed from the immersion bath and dried with hot air. Then they were immersed in a chromic acid $[20 \mathrm{~g}$ chromium (VI) oxide (1257, Vel, Belgium), 1 g $\mathrm{AgNO}_{3}$ (85228, Sigma Aldrich, Steinheim, Germany) and $100 \mathrm{~mL}$ distilled $\mathrm{H}_{2} \mathrm{O}$ ] for $30 \mathrm{~min}$ for the removal of the corrosion products. The DR was calculated in $\mathrm{mm} /$ year from the hydrogen generated and from the ML as indicated in equation 1 (1) and equation 2 (2), respectively. The gas volume, which was detected at the control position test, and the $\mathrm{H}_{2}$ solubility in DMEM were corrected in order to calculate the DR by $\mathrm{H}_{2}$.

$$
\mathrm{DR}=87.6 \frac{\mathrm{P}_{\mathrm{atm}} \mathrm{V}_{\mathrm{H} 2} \mathrm{M}}{\mathrm{R} \text { T A t } \rho}
$$

where $\mathrm{P}_{\mathrm{atm}}(1.013 \mathrm{~atm})$ is the atmospheric pressure, $\mathrm{H}_{2}$ volume corresponds to $\mathrm{V}_{\mathrm{H} 2}(\mathrm{~mL}), \mathrm{M}$ is $\mathrm{Mg}$ molar mass $\left(24.31 \mathrm{~g}^{2} \times \mathrm{mol}^{-1}\right), \mathrm{R}$ is the ideal gas constant $\left(0.082 \mathrm{~atm} \times \mathrm{L} \times \mathrm{mol}^{-1} \times \mathrm{K}^{-1}\right), \mathrm{T}$ is the temperature $(\mathrm{K}), \mathrm{A}$ is the sample area $\left(\mathrm{cm}^{2}\right), \mathrm{t}$ is the immersion time $(\mathrm{h})$ and $\rho$ is the alloy density $\left(\mathrm{g} \times \mathrm{cm}^{-3}\right)$.

$$
\mathrm{DR}=87600 \frac{\Delta \mathrm{W}}{\operatorname{At} \rho}
$$

where the mass difference between before testing and after chromic acid cleaning is $\Delta \mathrm{W}(\mathrm{g})$.

\section{In vivo experiments}

All animal experiments were performed under ethical respect for animals and were authorised by the Austrian ministry of science and research (accreditation number BMWF-66.010/0078-II/3b/2011). 3 male Sprague-Dawley rats ( $n=1$ rat per group) of $150-170 \mathrm{~g}$ of weight and 5 weeks of age were used within this study. Cylindrical pins of $1.6 \mathrm{~mm}$ diameter and $8 \mathrm{~mm}$ length of pure $\mathrm{Mg}, \mathrm{Mg}-10 \mathrm{Gd}$ and $\mathrm{Mg}-2 \mathrm{Ag}$ were used for the implantation. 2 pins of each alloy were implanted transcortically in the femoral bones of each rat. The entire implantation surgery took place under general anaesthesia and the postoperative treatment was described in detail by Kraus et al. (2012). $\mu$ CT scans were performed with Siemens Inveon $\mu \mathrm{CT}$ (Knoxville, TN, USA) at day 1 and 7 after the operation. During the $\mu \mathrm{CT}$ scans, the animals were anaesthetised with volatile isoflurane (Forane\#, Abbot AG, Baar, Switzerland). Siemens Inveon Acquisition Workplace 1.2.2.2 was the $\mu \mathrm{CT}$ scan software and scans of the rats were performed with a tungsten source at $70 \mathrm{kV}$ voltage, $500 \mu \mathrm{A}$ current and $1000 \mathrm{~ms}$ exposure time. The effective pixel size was 
Table 2. Composition in weight percent (wt.\%), impurity content in parts per million (ppm), grain size and density comparison of pure $\mathrm{Mg}, \mathrm{Mg}-10 \mathrm{Gd}$ and $\mathrm{Mg}-2 \mathrm{Ag}$ in disc and pin shape. $\mathrm{Fe}, \mathrm{Ni}$ and $\mathrm{Cu}$ impurity content was higher for pins than for discs due to the processing route and the lack of surface preparation.

\begin{tabular}{|c|c|c|c|c|c|c|c|c|c|c|c|c|c|}
\hline & & $\begin{array}{c}\text { Gd } \\
\text { wt.\% }\end{array}$ & $\begin{array}{c}\text { Ag } \\
\text { wt. } \%\end{array}$ & $\begin{array}{c}\mathrm{Fe} \\
\mathrm{ppm}\end{array}$ & $\begin{array}{l}\text { Mn } \\
\text { ppm }\end{array}$ & $\begin{array}{c}\mathrm{Si} \\
\mathrm{ppm}\end{array}$ & $\begin{array}{c}\mathrm{Ni} \\
\mathrm{ppm}\end{array}$ & $\begin{array}{c}\text { Co } \\
\text { ppm }\end{array}$ & $\begin{array}{c}\mathrm{Cu} \\
\mathrm{ppm}\end{array}$ & $\begin{array}{c}\text { Al } \\
\text { ppm }\end{array}$ & $\begin{array}{c}\text { Mg } \\
\text { wt.\% }\end{array}$ & $\begin{array}{c}\text { Grain size } \\
\mu \mathrm{m}\end{array}$ & $\begin{array}{c}\text { Density } \\
\mathrm{g} / \mathrm{cm}^{3}\end{array}$ \\
\hline \multirow{2}{*}{ pure Mg } & disc & - & - & 46 & 334 & 130 & 4 & 1 & 14 & 45 & balance & $22.6 \pm 5.2$ & 1.740 \\
\hline & pin & - & - & 161 & 217 & 147 & 14 & 3 & 20 & 20 & balance & $18.3 \pm 9.1$ & 1.742 \\
\hline \multirow{2}{*}{ Mg-10Gd } & disc & 8.63 & - & 47 & 101 & 55 & 9 & 1 & 2 & 97 & balance & $17.8 \pm 5.7$ & 1.854 \\
\hline & pin & 10.89 & - & 158 & 108 & 66 & 20 & 3 & 31 & 99 & balance & $19.9 \pm 7.4$ & 1.901 \\
\hline \multirow{2}{*}{ Mg-2Ag } & disc & - & 1.88 & 50 & 82 & 90 & 4 & 1 & 8 & 38 & balance & $43.7 \pm 8.5$ & 1.762 \\
\hline & pin & - & 1.80 & 357 & 86 & 105 & 14 & 2 & 17 & 38 & balance & $25.6 \pm 9.0$ & 1.757 \\
\hline
\end{tabular}
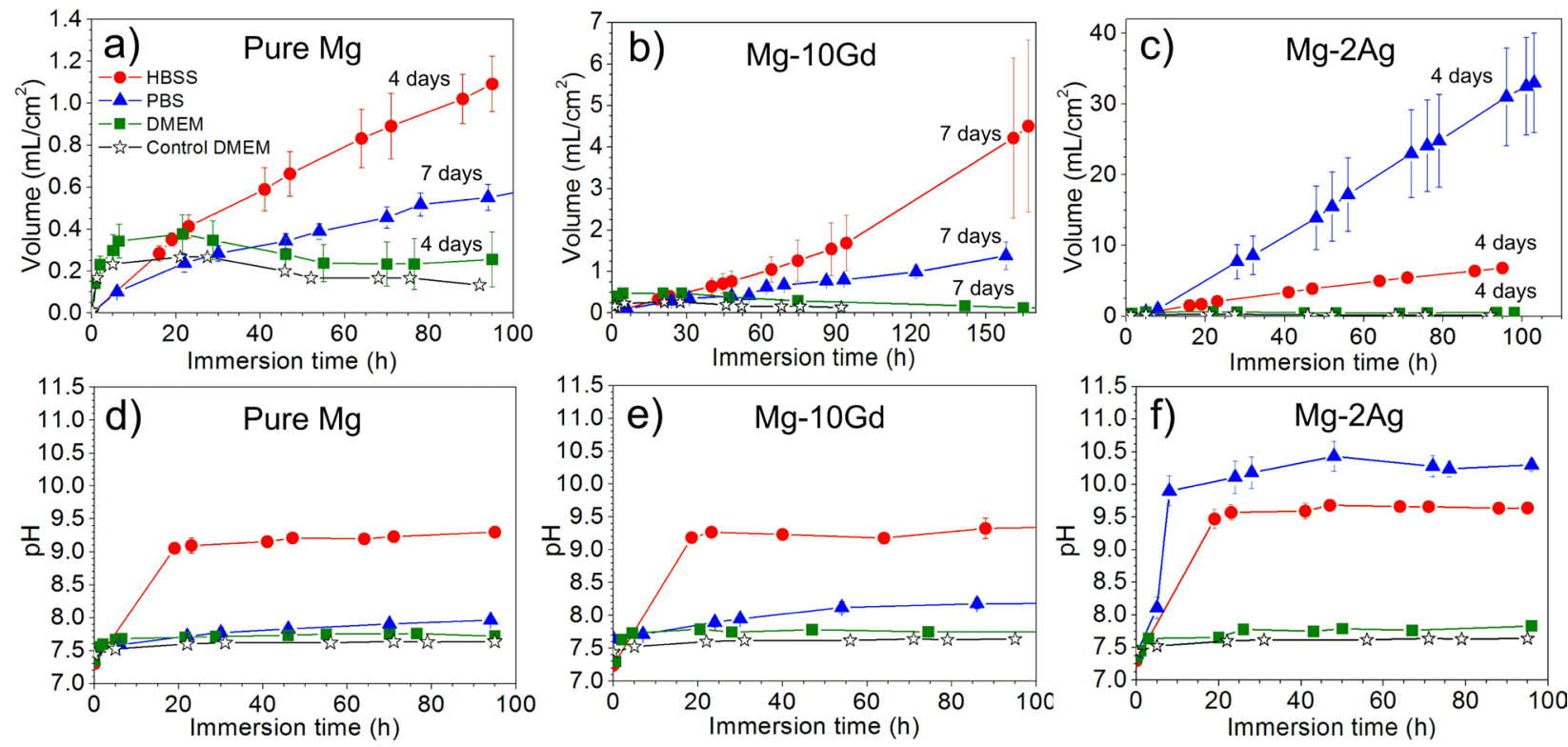

Fig. 2. Hydrogen evolution of (a) pure Mg, (b) Mg-10Gd and (c) Mg-2Ag, in PBS, HBSS and DMEM. pH evolution of (d) pure $\mathrm{Mg}$, (e) Mg-10Gd and (f) $\mathrm{Mg}-2 \mathrm{Ag}$ in the same media for the first $100 \mathrm{~h}$. Six samples were tested for each medium for 4-7 d; results are shown as means $\pm \mathrm{SD}$ (standard deviation). The total duration of each test is indicated next to each $\mathrm{H}_{2}$ evolution curve.

$35.04 \mu \mathrm{m}$. An aluminium filter with a thickness of $0.5 \mathrm{~mm}$ was used. 3D morphometric analysis was executed and the pin volume and surface and gas volume were evaluated by using the Mimics software (Version 18.0, Materialise, Leuven, Belgium) as described by Kraus et al. (2012).

The DR ( $n=2$ bones per group) was calculated in $\mathrm{mm} /$ year during the $7 \mathrm{~d}$ after the operation by the equation 3 :

$$
\mathrm{DR}_{\mathrm{i}}=\frac{\Delta \mathrm{x}_{\mathrm{i}}}{\Delta \mathrm{t}} \text { with } \Delta \mathrm{x}_{\mathrm{i}}=\frac{\Delta \mathrm{v}_{\mathrm{i}}}{\mathrm{s}_{\mathrm{i}}}
$$

where $\mathrm{i}$ is the observation time point, $\Delta \mathrm{V}_{\mathrm{i}}$ is the change of the volume between the observation time point $i-1$ and $\mathrm{i}(\Delta \mathrm{t})\left(\mathrm{mm}^{3}\right), \mathrm{S}_{\mathrm{i}}$ is the surface area at the observation time point $\mathrm{i}\left(\mathrm{mm}^{2}\right)$ and $\Delta \mathrm{x}_{\mathrm{i}}$ is the degradation width $(\mathrm{mm})$ (Fischerauer et al., 2013). As mentioned above, the time points $\mathrm{i}$ are 1 and $7 \mathrm{~d}$. Pin volume reduction was also calculated in percent during the $7 \mathrm{~d}$ after the operation.

Animals were euthanised $7 \mathrm{~d}$ after the operation as described in Kraus et al. (2012). Bones were explanted and directly frozen at $-80^{\circ} \mathrm{C}$. Then they were sent, preserved with dry ice, to KU Leuven for the degradation layer analysis.

\section{Degradation layer analysis}

Both in vitro and in vivo tested samples were embedded in a high infiltration epoxy resin and after cutting and polishing, they were coated with platinum by sputtering to make the surface electrically conductive. Elemental mapping was performed with cross sections of tested samples using the Electron Probe Micro Analysis device (EPMA, JEOL Ltd. JXA-8530F, Akishima, Tokyo, Japan). All maps were acquired at $10 \mathrm{kV}, 20 \mathrm{nA}$ and $30 \mathrm{~ms}$ per dwell time, which is the acquisition time per pixel. Additionally, images were acquired by scanning electron microscopy (SEM, XL30 FEG, Philips, Eindhoven, The Netherlands) and elemental point analysis by energy dispersive X-ray spectroscopy (EDX, EDAX, Tilburg, The Netherlands). Elemental mapping analysis was also performed in other studies to characterise the degradation layer formed on $\mathrm{Mg}$ samples (Agha et al., 2016; Willumeit et al., 2011). 


\section{Results}

\section{Material characterisation}

Table 2 shows the composition of the studied $\mathrm{Mg}$ alloys in disc and pin shape together with the impurity content of $\mathrm{Fe}, \mathrm{Mn}, \mathrm{Si}, \mathrm{Ni}, \mathrm{Co}, \mathrm{Cu}$ and $\mathrm{Al}$. The grain size and the alloy density are also included in Table 2 .

\section{Degradation tests}

In vitro immersion tests

Fig. 2 shows the gas and $\mathrm{pH}$ evolution of pure $\mathrm{Mg}, \mathrm{Mg}$ $10 \mathrm{Gd}$ and $\mathrm{Mg}-2 \mathrm{Ag}$ as function of time in PBS, HBSS and DMEM. Pure Mg and Mg-10Gd showed similar $\mathrm{H}_{2}$ evolution curves in PBS and HBSS (Fig. 2a,b), although HBSS was slightly more aggressive than PBS to these two alloys. The $\mathrm{pH}$ was higher in HBSS (9-9.5) than in PBS $(<8.5)$ during the entire immersion time, demonstrating that HBSS had a weaker buffering power (Fig. 2d-f). Instead, $\mathrm{Mg}-2 \mathrm{Ag}$ had a higher $\mathrm{H}_{2}$ evolution slope in PBS than in HBSS (Fig. 2c). The $\mathrm{pH}$ in this case was lower in PBS (9-9.5) than in HBSS (10-10.5) (Fig. 2f). Thus, a lower $\mathrm{H}_{2}$ evolution slope corresponded to a lower DR and, consequently, a lower $\mathrm{pH}$ value was measured.

In DMEM the biodegradation process was slower for all three $\mathrm{Mg}$ based materials. A first gas increase was measured for the three materials during the first $10 \mathrm{~h}$ in DMEM reaching a maximum collected gas of $0.3-0.6 \mathrm{~mL} /$ $\mathrm{cm}^{2}$ (Fig. 2). Then, the gas volume decreased during the rest of the immersion time with an approximate rate of $0.1 \mathrm{~mL} / \mathrm{cm}^{2} / \mathrm{d}$. Within the position control test (without samples), a similar gas evolution was registered, but lower in volume, proving that some of the gas measured was $\mathrm{CO}_{2}$ from the buffering system (Fig. 2a,b). Due to the nature of the biodegradation process of $\mathrm{Mg}$, the rest must be $\mathrm{H}_{2}$. The initial $\mathrm{pH}$ of DMEM was 7.4, but during testing the $\mathrm{pH}$ increased, getting stabilised at values between 7.7 and 7.9. The control position also revealed a $\mathrm{pH}$ of 7.6-7.7, which corresponded to the $\mathrm{pH}$ range of DMEM in $5 \% \mathrm{CO}_{2}$. This indicated an increase of $\mathrm{pH}$ smaller than 0.3 between tests with and without Mg samples in DMEM. The fluctuation of the atmospheric pressure can also be a source of errors in the $\mathrm{H}_{2}$ data recording, but it is considered the smallest

Table 3. DR of pure $\mathrm{Mg}, \mathrm{Mg}-10 \mathrm{Gd}$ and $\mathrm{Mg}-2 \mathrm{Ag}$ in $\mathrm{mm} / \mathrm{year}$, calculated from the hydrogen collection and mass loss in PBS, HBSS, DMEM and by pin volume and surface in vivo at the end of each test.

\begin{tabular}{|c|c|c|c|c|}
\hline & Mass loss & $\begin{array}{c}\text { DR pure Mg } \\
{[\mathbf{m m} / \text { year] }}\end{array}$ & $\begin{array}{c}\text { DR Mg-10Gd } \\
{[\mathbf{m m} / \text { year] }}\end{array}$ & $\begin{array}{c}\text { DR Mg-2Ag } \\
{[\mathrm{mm} / \text { year] }}\end{array}$ \\
\hline PBS & Hydrogen & $0.19 \pm 0.07$ & $0.61 \pm 0.10$ & $16.71 \pm 3.06$ \\
\hline PBS & Mass loss & $0.72 \pm 0.31$ & $1.57 \pm 0.62$ & $15.12 \pm 2.97$ \\
\hline HBSS & Hydrogen & $0.57 \pm 0.07$ & $1.23 \pm 0.56$ & $3.41 \pm 0.71$ \\
\hline HBSS & Mass loss & $1.07 \pm 0.10$ & $0.42 \pm 0.12$ & $2.21 \pm 0.26$ \\
\hline DMEM & Hydrogen & $0.57 \pm 0.07$ & $0.20 \pm 0.01$ & $0.68 \pm 0.04$ \\
\hline DMEM & Pin volume & $0.15 \pm 0.03$ & $1.11 \pm 0.05$ & $0.13 \pm 0.04$ \\
\hline In vivo & and surface & \multicolumn{3}{|l}{} \\
\hline
\end{tabular}

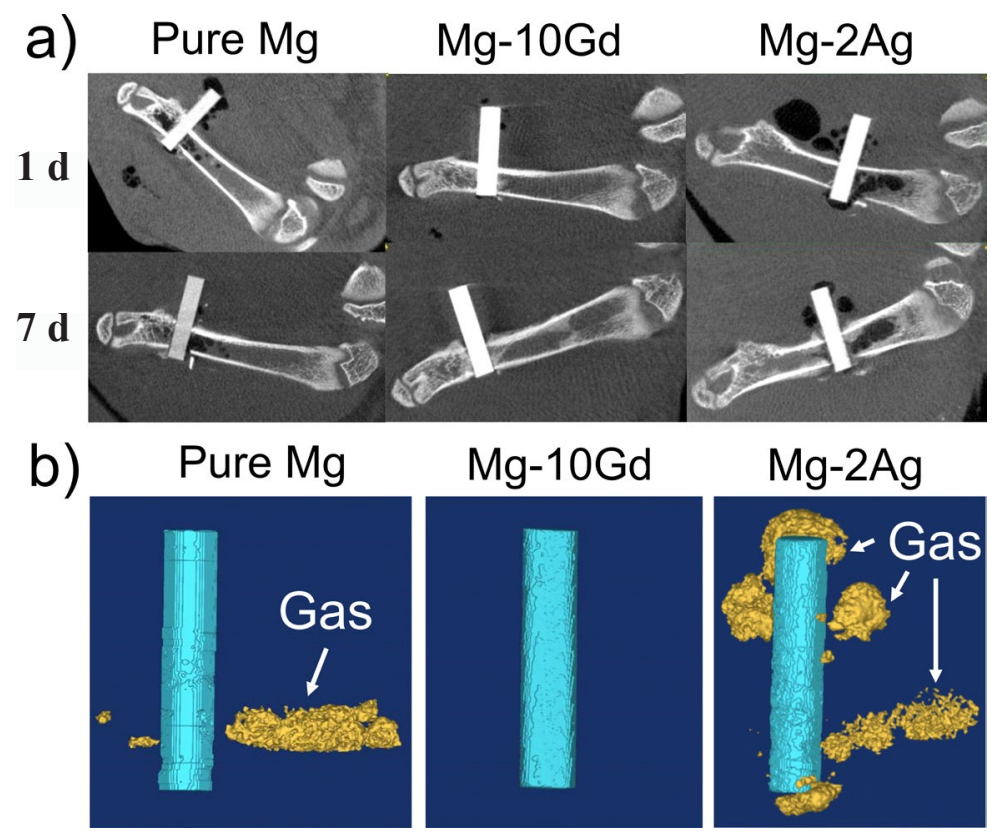

Fig. 3. (a) $\mu \mathrm{CT}$ scans of Sprague-Dawley rats implanted with Pure $\mathrm{Mg}, \mathrm{Mg}-10 \mathrm{Gd}$ and $\mathrm{Mg}-2 \mathrm{Ag}$ alloys 1 and $7 \mathrm{~d}$ after the operation. The effective pixel size was $35 \mu \mathrm{m}$. (b) 3D reconstructed images of the different alloys with the surrounding gas release $7 \mathrm{~d}$ post-operative. 
error, as shown by Hofstetter et al. (2015b). In Fig. 2, in some cases, the test was finished prematurely at day 4 for different reasons: (1) in PBS and HBSS, Mg-2Ag exceeded the limit of the gas storage capacity, (2) for pure $\mathrm{Mg}$ in PBS a linear behaviour was expected, as it was measured with Mg-10Gd, (3) in DMEM, the test with pure Mg and $\mathrm{Mg}-2 \mathrm{Ag}$ was interrupted due to risk of contamination by microorganisms after day 4, even though sterile conditions were equally applied in all the tests. This contamination was detected when the DMEM became turbid and the $\mathrm{pH}$ started to decrease.

In PBS and HBSS, severe localised and pitting corrosion could be observed on $\mathrm{Mg}-2 \mathrm{Ag}$, while pure $\mathrm{Mg}$ and Mg-10Gd showed generally a homogeneous corrosion mode. A less aggressive degradation process was observed in DMEM. In this case, the degradation was homogeneous for every Mg-based material.

\section{In vitro degradation rate}

DRs were calculated starting from ML and hydrogen generation. DR results at the end of the immersion in each test condition are shown in Table 3. ML and $\mathrm{H}_{2}$ methods correlated closely. DRs given by these two methods showed systematically higher values for ML than for $\mathrm{H}_{2}$ evolution.
According to the ML method, pure Mg degraded slower than $1.1 \mathrm{~mm} /$ year in every testing condition. Also, Mg$10 \mathrm{Gd}$ degraded at low DR in the three conditions. Finally, the DR of Mg-2Ag decreased from $16.7 \mathrm{~mm} /$ year in PBS to $5.4 \mathrm{~mm} /$ year in HBSS and $2.2 \mathrm{~mm} /$ year in DMEM. Thus, Mg-2Ag showed the highest DR in the three testing conditions compared to pure $\mathrm{Mg}$ and $\mathrm{Mg}-10 \mathrm{Gd}$.

\section{In vivo degradation rate}

The $\mu \mathrm{CT}$ scans in Fig. 3 show the degradation performance after $7 \mathrm{~d}$ of implantation of pure $\mathrm{Mg}, \mathrm{Mg}-10 \mathrm{Gd}$ and $\mathrm{Mg}$ 2Ag.

After $1 \mathrm{~d}$ of implantation, the $\mu \mathrm{CT}$ scan images with pure $\mathrm{Mg}$ showed gas formation in the intramedullary cavity around the implant as well as in the surrounding tissue. $7 \mathrm{~d}$ after the operation, the gas was localised only within the intramedullary cavity around the implant. $7 \mathrm{~d}$ after the implantation, the gas volume was $3.4 \pm 1.93 \mathrm{~mm}^{3}$ (Fig. 3 b). Bone contact was observed since the first day due to the press fit implantation procedure of the pin.

In $\mathrm{Mg}-10 \mathrm{Gd} \mu \mathrm{CT}$ scan images, very small pockets of gas bubbles were observed in the tissue surrounding the implant $1 \mathrm{~d}$ after the implantation. $7 \mathrm{~d}$ after the operation, the gas formation was not obvious and calculated to be

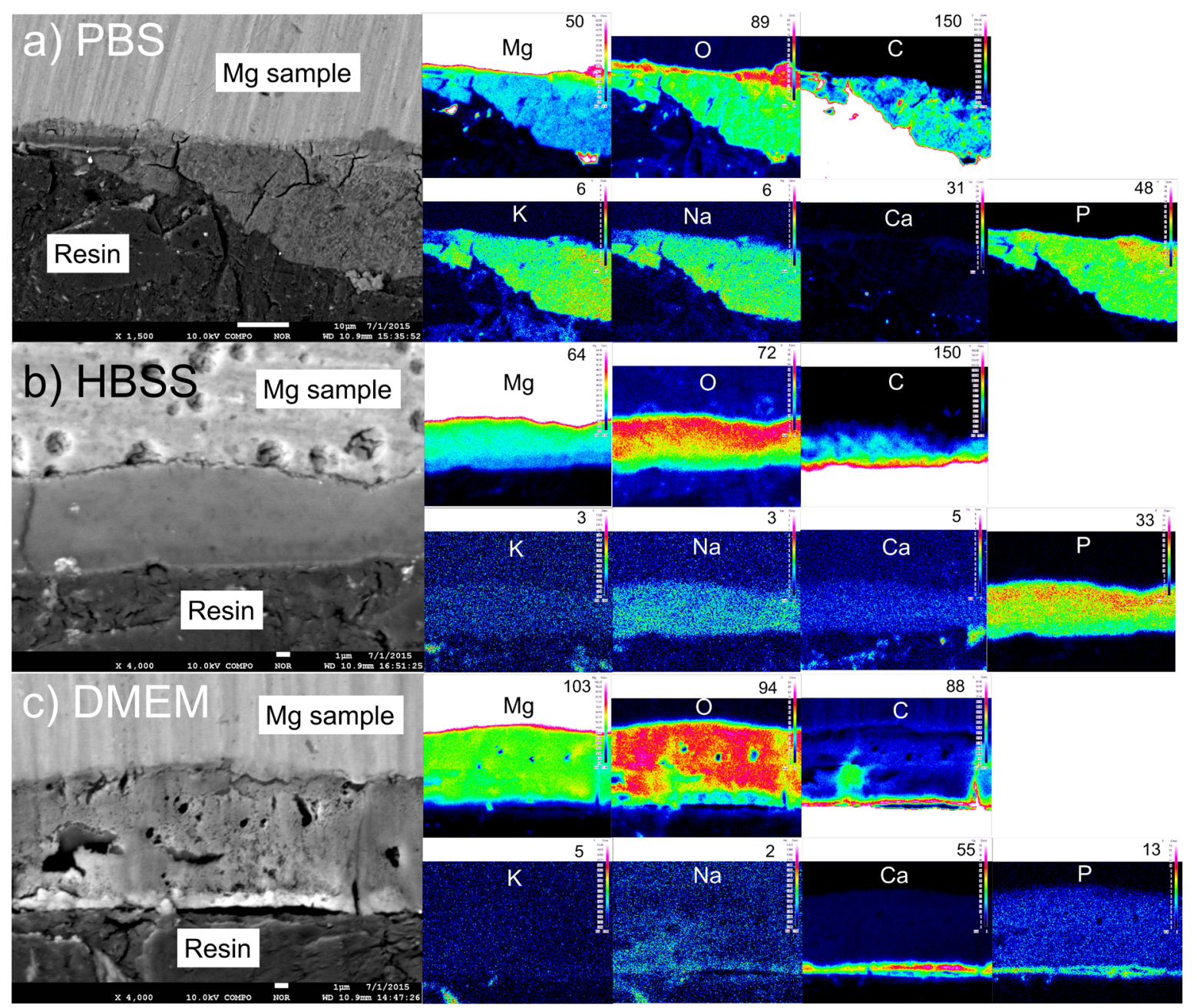

Fig. 4. Elemental mapping of the degradation layer formed on pure Mg samples immersed in (a) PBS, (b) HBSS and (c) DMEM for $7 \mathrm{~d}$. The number on top of each picture indicates the maximum intensity on the scale bar. PBS maps were acquired with a resolution of $0.5 \times 0.5 \mu \mathrm{m}$ in approximately $75 \mathrm{~min}$, while HBSS and DMEM maps were acquired in $1 \mathrm{~h}$ with a resolution of $0.1 \times 0.1 \mu \mathrm{m}$. 


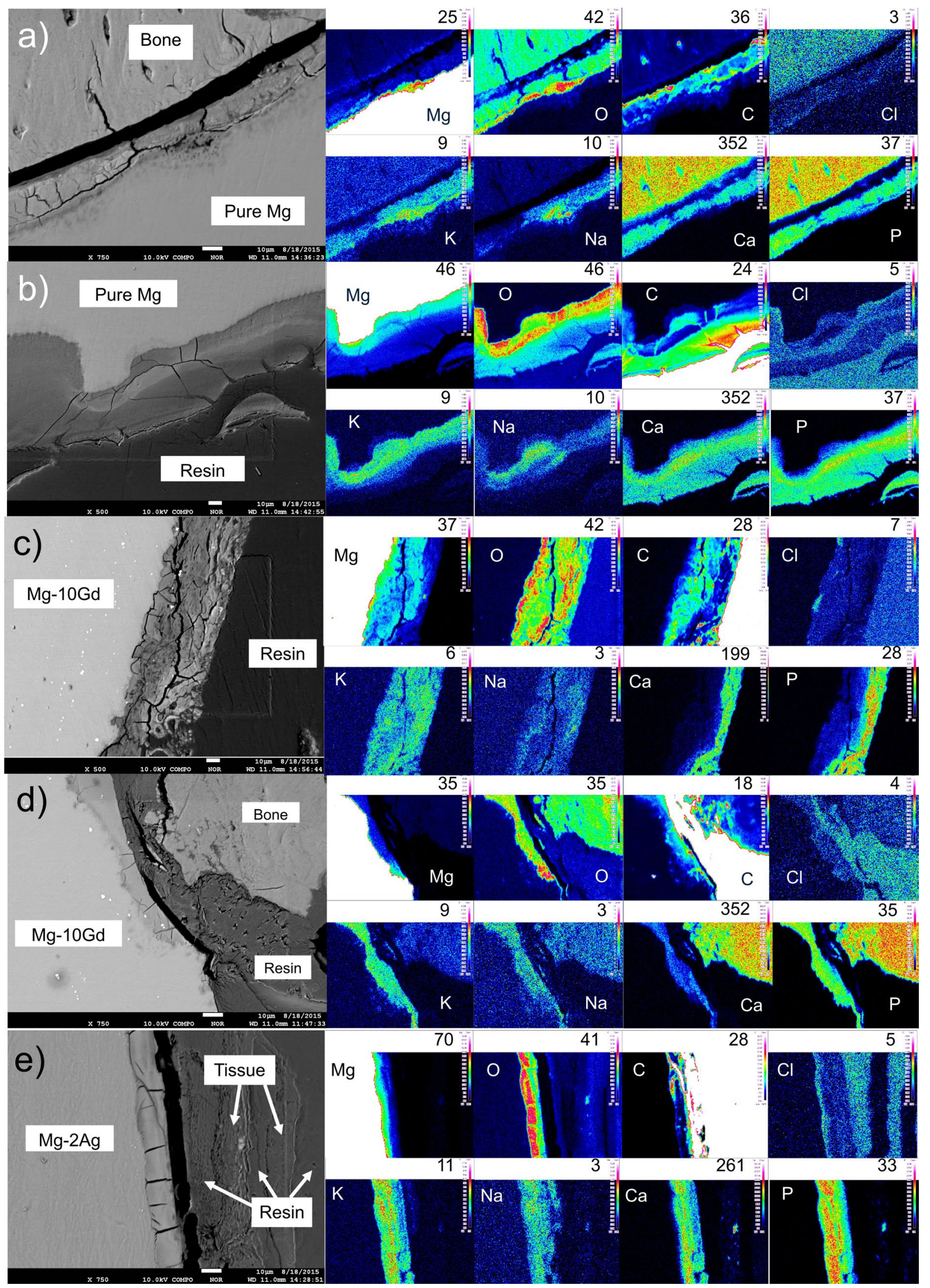

Fig. 5. Elemental mapping of the degradation layer formed on implanted pins after $7 \mathrm{~d}$. Different sites on each $\mathrm{Mg}$ based material are analysed: (a) pure $\mathrm{Mg}$ in close contact with cortical bone; (b) pure $\mathrm{Mg}$ at the intramedullary cavity; (c) Mg-10Gd at the intramedullary cavity; (d) Mg-10Gd in the vicinity of the cortical bone; (e) Mg-2Ag at the intramedullary cavity. The elements mapped with different colour contrasts are $\mathrm{Mg}, \mathrm{O}, \mathrm{C}, \mathrm{Cl}, \mathrm{K}, \mathrm{Na}, \mathrm{Ca}$ and $\mathrm{P}$. All maps were acquired with a resolution of $0.5 \times 0.5 \mu \mathrm{m}$ in approximately $75 \mathrm{~min}$. The scale on the upper-right site of each elemental map is an approximation of the concentration of that element corresponding to the maximum of the scale bar. White scale bars at each SEM image correspond to $10 \mu \mathrm{m}$. 
$0.23 \pm 0.32 \mathrm{~mm}^{3}$ (Fig. 3b). In Mg-10Gd, the bone contact seemed to be tight since the first post-operative day, likely due to the press fit implantation of the pin.

$1 \mathrm{~d}$ after implantation, $\mathrm{Mg}-2 \mathrm{Ag} \mu \mathrm{CT}$ scan images showed a large amount of gas formation within the intramedullary cavity around the implant as well as in the surrounding tissue. $7 \mathrm{~d}$ after the operation, the gas bubbles were decreased in the surrounding tissue, but they were still present in the intramedullary cavity around the implant. The gas volume $7 \mathrm{~d}$ after the implantation was calculated to be $6.52 \pm 8.41 \mathrm{~mm}^{3}$ (Fig. 3b). Tight bone contact was also observed since the first day.

In vivo DRs, calculated from the pin volume loss and pin surface measured $7 \mathrm{~d}$ after implantation, are shown in Table 3. A smaller loss of pin volume was calculated for $\mathrm{Mg}$ and $\mathrm{Mg}-2 \mathrm{Ag}$ pins, which was comparable to the low DR of these materials in DMEM. A high DR of Mg-10Gd pin in vivo as compared to the low DR of Mg-10Gd discs in any in vitro immersion test was highlighted.

In all $\mu \mathrm{CT}$ images, no biodegradation was evident by visual examination alone, but slight pin volume reductions could be calculated using the Mimics software.

In vivo $\mu \mathrm{CT}$ results were used to examine bone growth and degradation behaviour, in order to provide proper information on volume and surface in the ongoing degradation process in the living animals. Unfortunately, a higher resolution and better contrast between degradation layer and bone was only possible after the explantation of the bone and the use of higher resolution ex vivo scanning protocols.

\section{Degradation layers \\ In vitro}

The degradation layers formed on pure Mg in PBS, HBSS and DMEM, analysed by elemental mapping, are shown in Fig. 4a-c. Mg-10Gd and Mg-2Ag are not shown because pure $\mathrm{Mg}$ represent closely the surface layers formed on these three electrolytes in the three condition.

In PBS, a layer containing $\mathrm{Mg}, \mathrm{O}, \mathrm{P}$ and $\mathrm{C}$ with traces of $\mathrm{Na}$ and $\mathrm{K}$ was identified (Fig. 4a). C was also present although $\mathrm{PBS}$ does not contain any $\mathrm{C}$ source. In HBSS, also $\mathrm{Mg}, \mathrm{O}, \mathrm{P}, \mathrm{C}$ and traces of $\mathrm{Na}, \mathrm{K}$ and $\mathrm{Ca}$ were detected (Fig. 4b): low $\mathrm{O}$ and high $\mathrm{C}$ levels were found on the outside of the degradation layer,while $\mathrm{P}$ level was high on the inner side of the degradation layer. In DMEM, the degradation layer contained different elements in two different regions, one rich in $\mathrm{Mg}, \mathrm{O}$ and $\mathrm{C}$ and another one in $\mathrm{P}$ and $\mathrm{Ca}$ (Fig. $4 \mathrm{c}$ ). In some cases there was a rim next to the $\mathrm{Mg}$ sample or the $\mathrm{C}$ containing resin which was an artefact caused by the large interaction volume of the beam.

\section{In vivo}

The degradation layers formed on pure $\mathrm{Mg}, \mathrm{Mg}-10 \mathrm{Gd}$ and $\mathrm{Mg}-2 \mathrm{Ag}$ in vivo were characterised by elemental mapping (Fig. 5). Different layers were found in vivo, with different thickness and composition depending on the location (Fig. 6).Thus, two areas have been characterised for pure $\mathrm{Mg}$ and $\mathrm{Mg}-10 \mathrm{Gd}$. Fig. 5a shows pure $\mathrm{Mg}$ in close contact with cortical bone. The elemental mapping indicated higher $\mathrm{Ca}$ and $\mathrm{P}$ levels in the bone compared to the degradation layer. Bone also contained traces of $\mathrm{Cl}$.
Sites rich in $\mathrm{Mg}$ and $\mathrm{O}$ were found in the area next to the $\mathrm{Mg}$ sample. $\mathrm{Na}$ and $\mathrm{K}$ were also incorporated in this layer. The $\mathrm{C}$ rich area highlighted the presence of biological entities. Fig. $5 \mathbf{b}$ shows a much thicker layer without bone contact. As a result, this region was more exposed to the environment and to the body fluid flow, which caused a faster degradation in this area. This faster degradation translated into a thicker surface film where clear differences in elemental content were distinguished. Conversely, Fig. 6c shows an exception to this observation, since there was a relatively thick layer on the $\mathrm{Mg}$ pin in contact with cortical bone, which presumably was related to a higher body fluid flow through this site. On the inner side, next to the $\mathrm{Mg}$ based material, were found higher levels of $\mathrm{Mg}$ and $\mathrm{O}$ compared to the outer side of the same layer. In this area also a higher $\mathrm{K}, \mathrm{Na}$ and $\mathrm{Cl}$ and slightly higher $\mathrm{Ca}$ and $\mathrm{P}$ contents were detected. At the outer side, a higher $\mathrm{C}$ content was detected, which could indicate the presence of carbonate products. It is noteworthy that the resin applied for the sample preparation contained $\mathrm{Cl}$, which could be confused with the $\mathrm{Cl}$ measured at the degradation layer, especially in such a low a concentration.

Fig. 5c,d depict the elemental mapping of the degradation layer formed on $\mathrm{Mg}-10 \mathrm{Gd}$ in vivo. Fig. 5c shows a region of the implant without bone contact. This area contains $\mathrm{Mg}, \mathrm{O}, \mathrm{C}, \mathrm{K}, \mathrm{Ca}$ and $\mathrm{P}$ homogeneously distributed and traces of $\mathrm{Na}$ and $\mathrm{Cl}$. $\mathrm{Ca}$ and $\mathrm{P}$ were more intensely detected at the outer side of the rim, which can be commonly found along the surface layer. These $\mathrm{Ca}$ and $\mathrm{P}$ containing sites were also observed in Fig. $5 \mathbf{b}$. Fig. $5 \mathbf{d}$ shows a region of the implant in the vicinity of the original femoral bone. Mainly $\mathrm{Mg}, \mathrm{O}, \mathrm{C}, \mathrm{Ca}$ and $\mathrm{P}$ were found together with $\mathrm{K}$ and traces of $\mathrm{Na}$ and $\mathrm{Cl}$. This layer on $\mathrm{Mg}-10 \mathrm{Gd}$ had no significant differences to the one observed on pure Mg in Fig. 5a,b. Moreover, similarly to Fig. 5a,b, a difference in $\mathrm{Ca}$ and $\mathrm{P}$ between bone and degradation layer was highlighted with, perhaps, a small change in the $\mathrm{Cl}$ content.

Finally, the elemental analysis of the degradation layer formed on $\mathrm{Mg}-2 \mathrm{Ag}$ at the medullary cavity is shown in Fig. 5e. On the one hand, $\mathrm{Mg}$ and $\mathrm{O}$ were homogeneously distributed, with a higher concentration in the inner part of the layer compared to the outer side. On the other hand, the $\mathrm{C}$ content varied substantially in different areas. The $\mathrm{Cl}$ content could indicate the presence of the resin. The observed concentration variations could be explained by the presence of tissue, since no bone was visible. Also, the $\mathrm{Cl}$ content might be slightly higher at the inner side of the degradation layer next to the $\mathrm{Mg}-2 \mathrm{Ag}$ implant, although the $\mathrm{Cl}$ concentration detected was rather low.

As shown in Fig. 6, the degradation layer thickness varied depending on the local environment where the sample was degrading. After $7 \mathrm{~d}$ of implantation, the thickness of the surface layer developed at the intramedullary cavity was $67.5 \pm 19.4 \mu \mathrm{m}$ (Fig. 6b) and at the outer part of the cortical femoral bone was $15.8 \pm 3.3 \mu \mathrm{m}$ (Fig. 6a). There were also differences at different implant-bone contact sites. Fig. 6a,c show two different sites where bone was in contact with the degradation layer. The degradation layer at the inner side of the cortical bone shown in Fig. $6 \mathbf{c}$ had a thickness of $40.9 \mu \mathrm{m}$. 


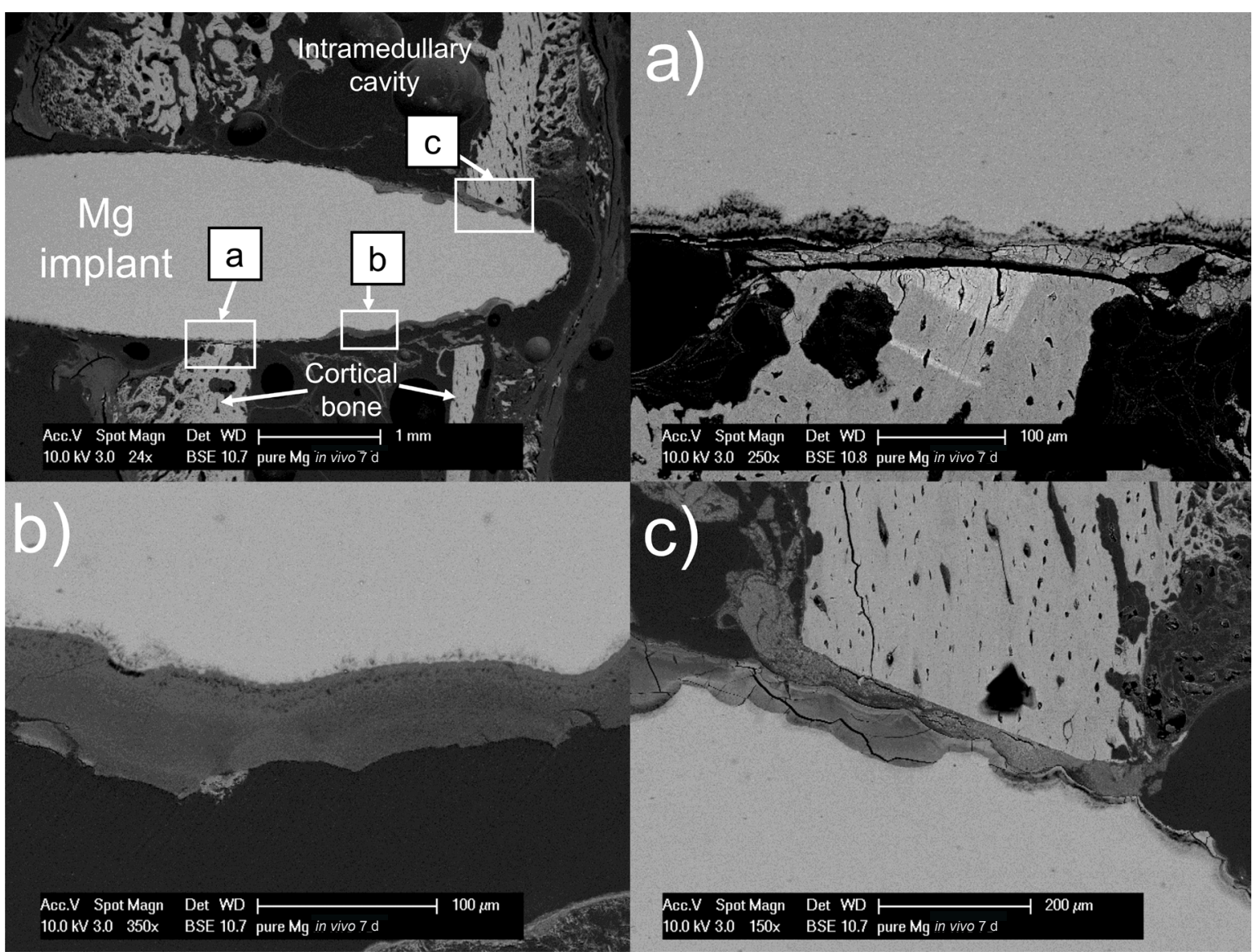

Fig. 6. SEM images of pure Mg implanted for $7 \mathrm{~d}$ show differences in degradation layer depending on the bone contact and the environment around the implant. (a) Slow degrading site characterised by a thin degradation layer deposition at an implant-bone contact site. (b) Thick degradation layer in the intramedullary cavity indicating a faster corrosion process. (c) Degradation layer at an implant-bone contact site, where a thicker layer related to a faster degradation process is observed. This is an exception to the observations from Fig. 5b,c, where a faster degradation was observed at the intramedullary cavity.

\section{Initial surface}

As shown in Fig. 7, the surface of the studied discs and pins has been analysed in order to determine the status of the surface before the immersion and in vivo tests, respectively. As mentioned above, discs have been ground and polished before in vitro immersion tests. The contact with air and moisture can generate a thin oxide film, which has been quantified by EDX in Fig. 7a. The O/Mg ratio can indicate the thickness of the oxide film. On the one hand, this $\mathrm{O} / \mathrm{Mg}$ ratio for such polished samples was lower than 0.1 , and on the other hand, pins which have been delivered, sterilised and stored for 1 to 2 years, showed a $\mathrm{O} / \mathrm{Mg}$ ratio between 0.4 and 0.55 . These oxides are also shown in Fig. $7 \mathbf{b}$ and can be identified as the grey areas on the pin surface. Fig. $7 \mathbf{b}$ closely represents the state of the surface finish of the $\mathrm{Mg}$ pins implanted. It has been recently proven that storage can have an influence on the degradation behaviour of $\mathrm{Mg}$ based materials; thus, while storing the material, a natural ageing process has been observed as well as an increase in oxygen-enriched regions on the implant surface (Bracht et al., 2015). Thus, the pins are more oxidised compared to freshly ground discs applied in this study.

However, the thickness of this oxide layer was noticeably smaller than the degradation layer, due to the energy applied during the SEM $(20 \mathrm{kV})$ and since $\mathrm{Mg}$ could still be detected through the greyish layer (see brighter areas within the grey areas in Fig. 7b). Thus, the thickness of the oxide layer was considered to be at least thinner than $1 \mu \mathrm{m}$, while the degradation layer will be thicker than $10 \mu \mathrm{m}$, in any case. Thus, the influence of this oxide layer is considered to be moderate.

Furthermore, as depicted in Fig.7c,d, impurity particles were also observed on the pin surface. These two images are examples of the many different impurity particles that could be found attached to the surface. The EDX spectrum from Fig. 7c shows clear Fe, $\mathrm{Cr}$ and Ni peaks, presumably indicating that these particles came from a stainless steel tool used for the extrusion or the machining. Fig. 7d shows another particle containing $\mathrm{Cu}$ and $\mathrm{Zn}$, which might come from the original material or from contamination during casting, i.e. previous castings on the same permanent mould. Thus, the surface preparation (or the lack of it) might have an influence on the in vivo behaviour.

\section{Discussion}

\section{Degradation layer}

In PBS, the degradation layer was mainly formed by $\mathrm{Mg}(\mathrm{OH})_{2}$ and $\mathrm{Mg}-\mathrm{PO}_{4}$ mixed in a non-distinguishable 

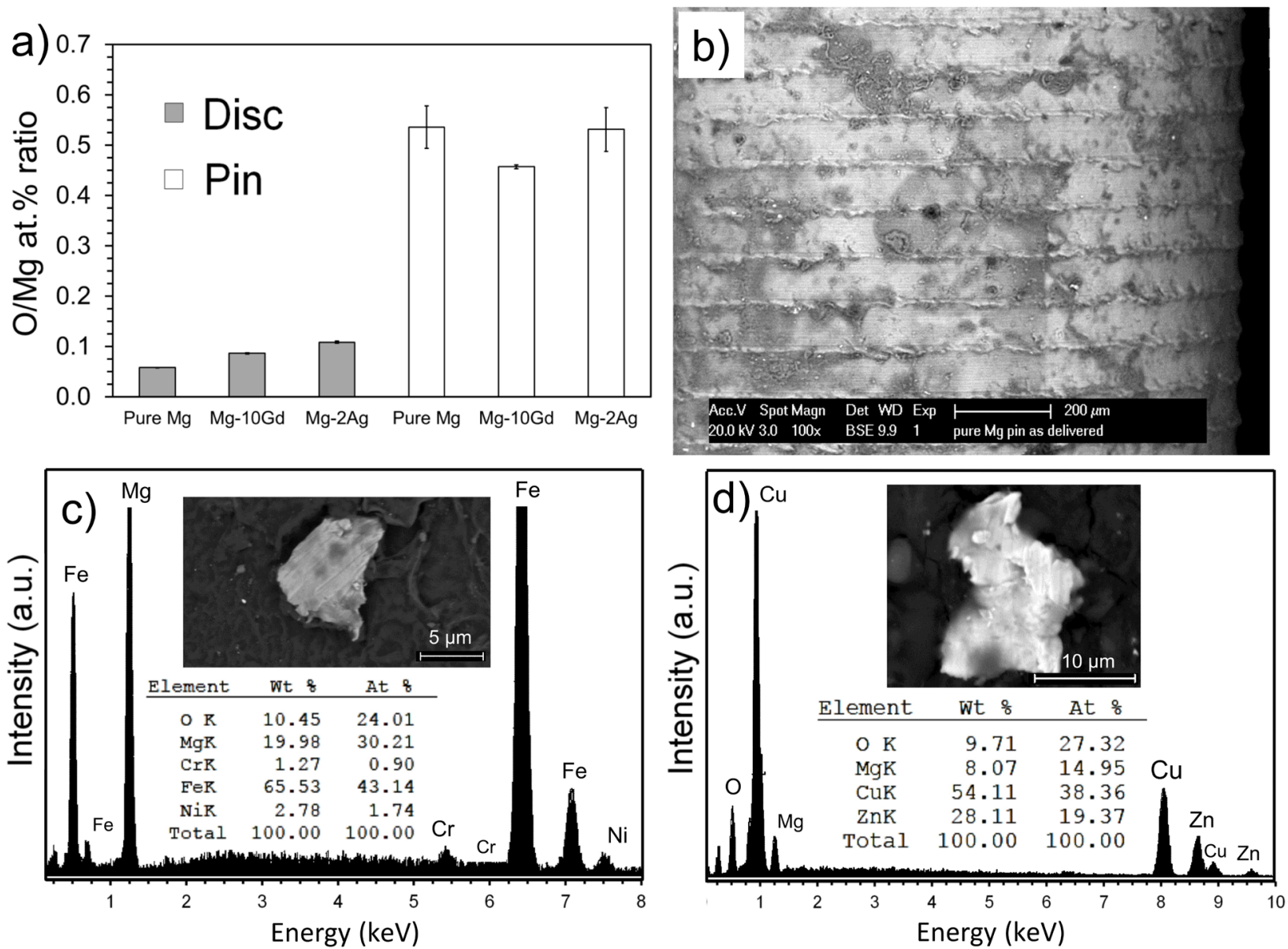

Fig. 7. Surface characterisation of the studied pins and discs tested. (a) Discs showed a lower oxidation level by EDX analysis compared to pins, which did not get any surface preparation. (b) Surface morphology in low magnification as an overview of the pin surface. The horizontal lines are machining marks due to turning. (c,d) Two impurity particles and their respective EDX point analysis. These particles came from the processing and the starting material.

manner due to a co-formation process (Fig. 3a). When the concentration of certain elements reaches the solubility limit, different compounds form the degradation layer. Moreover, in PBS, potassium phosphate can also nucleate on the surface and grow as a crystalline structure (Trinidad et al., 2013). This phenomenon is explained by the large amount of phosphate ions present in PBS. It is possible that the $\mathrm{C}$ detected was an artefact of sample preparation, presumably due to a smearing effect of the resin. The degradation layer in PBS was generally non-uniform, with a changing thickness. In HBSS, the degradation layer was similar, with $\mathrm{Mg}(\mathrm{OH})_{2}$ and $\mathrm{Mg}-\mathrm{PO}_{4}$ but also a small amount of $\mathrm{Mg}_{-} \mathrm{CO}_{3}$ (Fig. 3b). In contrast to products formed in PBS, no potassium phosphate crystals were found due to the small amount of $\mathrm{PO}_{4}^{3-}$ in solution. Finally, as demonstrated in Fig. 3c, the degradation layer in DMEM was composed of two layers. As reported in our previous work (Marco et al., 2016), the first one, next to the alloy surface, contained $\mathrm{Mg}(\mathrm{OH})_{2}$ and $(\mathrm{Mg}, \mathrm{Ca})-\mathrm{CO}_{3}$. The second layer, on top of the first one, was a thin $(\mathrm{Mg}, \mathrm{Ca})-\mathrm{PO}_{4}$ layer, which was observed in Fig. 4c.

The degradation layer formed in vivo was comparable to the one observed in DMEM test condition. The detection of $\mathrm{Mg}$ and $\mathrm{O}$ indicated the presence of $\mathrm{Mg}(\mathrm{OH})_{2} ; \mathrm{C}$ indicated $(\mathrm{Mg}, \mathrm{Ca})-\mathrm{CO}_{3}$ and $\mathrm{Ca}$ and $\mathrm{P}$ indicated $\mathrm{Ca}-\mathrm{PO}_{4}$ corrosion products. Supporting this hypothesis, Yang and Zhang as well as Zong et al., reported $\mathrm{Ca}_{3} \mathrm{Mg}_{3}\left(\mathrm{PO}_{4}\right)_{4}$ to be present at the surface layer formed in Hanks solution by XRD (Yang and Zhang, 2009; Zong et al., 2012). Hence, $\mathrm{Ca}-\mathrm{P}$ layer might also include $\mathrm{Mg}$ in its structure, so that $\mathrm{Ca}-\mathrm{P}$ can be defined as $(\mathrm{Mg}, \mathrm{Ca})-\mathrm{PO}_{4}$. The structure of this compound could be amorphous and further studies could clarify this matter. It was also possible to detect $\mathrm{Na}$ and $\mathrm{K}$ at a low concentration, which indicates that these two elements could also form phosphates or carbonates. The distribution of $\mathrm{Na}$ and $\mathrm{K}$ was homogeneous, meaning that these elements were distributed along the degradation layer by a co-formation process. Similarly to what was observed in DMEM (Fig. 3c), in animal experiments, Ca and $\mathrm{P}$ rich layers could also be formed separately from $\mathrm{Mg}(\mathrm{OH})_{2}$ and $(\mathrm{Mg}, \mathrm{Ca})-\mathrm{CO}_{3}$ (Fig. 5c). Hence, this finding indicates the importance of the presence of $\mathrm{Ca}^{2+}$ and $\mathrm{PO}_{4}{ }^{3-}$ ions in the electrolyte in order to allow calcium phosphate formation, which leads to a degradation layer in DMEM comparable to the one formed in vivo (Fig. 3c and Fig. 5). Some authors already reported the presence of these layers on Mg-based materials tested in HBSS (Kuwahara et al., 2001; Yang and Zhang, 2009; Zong et al., 2012), in DMEM (Willumeit et al., 2011), in blood (Feyerabend et al., 2015), in SBF (Zhang et al., 2009) and in animal experiments (Li 
et al., 2008; Xu et al., 2007). Agha et al., recently showed the influence of different inorganic salts such as $\mathrm{Ca}^{2+}$, $\mathrm{SO}_{4}{ }^{2-}$ and $\mathrm{HCO}_{3}^{-}$, present in cell culture media, on the $\mathrm{Mg}$ degradation process and the degradation layer formation (Ca-P and $\mathrm{Mg}-\mathrm{CO}_{3}$ products) (Agha et al., 2016). This demonstrates that DMEM is a testing medium closer to a more realistic situation, when sterilisation is assured, in comparison to PBS and HBSS without $\mathrm{Ca}^{2+}$ also used in this study.

Along the surface layer formed in vivo, differences in thickness and composition can be found. Thus, it is difficult to identify one representative area of the whole degradation layer. These differences are caused by the environment in which the implant surface finds itself. Many influencing factors, such as bone contact, growth, fluid flow, its composition and biological content (e.g. osteoclasts and osteoblasts) can be measured.

It is also noteworthy that bone had higher $\mathrm{Ca}$ and $\mathrm{P}$ levels than the degradation layer, which could help to distinguish them (Fig. 5a,d). Thus, these Ca-P containing corrosion products have a different composition from hydroxyapatite, which is only composed of $\mathrm{Ca}, \mathrm{P}$ and $\mathrm{O}$ (and traces of $\mathrm{Cl}$ ) while the degradation layer also contains hydroxides and carbonates.

\section{Degradation rate analysis \\ In vitro}

In vitro and in vivo degradation behaviours of pure $\mathrm{Mg}$, $\mathrm{Mg}-10 \mathrm{Gd}$ and $\mathrm{Mg}-2 \mathrm{Ag}$, all in disc and pin shape, were compared during the first $7 \mathrm{~d} . \mathrm{Mg}-2 \mathrm{Ag}$ discs showed the highest DR in the three in vitro testing conditions compared to pure $\mathrm{Mg}$ and $\mathrm{Mg}-10 \mathrm{Gd}$. This could be explained by the presence of $1.88 \mathrm{wt} \%$ (weight percent) of $\mathrm{Ag}$, a larger grain size $(43.7 \mu \mathrm{m})$ and large amount of $\mathrm{Cl}^{-}$in PBS and HBSS. Ag is considered as an impurity, which accelerates the $\mathrm{Mg}$ degradation process (Friedrich and Mordike, 2006) by dissolving $\mathrm{Mg}$ around Ag-rich particles and releasing these particles. A greater $\mathrm{Cl}^{-}$content in the electrolyte (e.g. in PBS and HBSS) will promote $\mathrm{Mg}(\mathrm{OH})_{2}$ dissolution (Mueller et al., 2009), exposing Mg and Ag and accelerating the degradation process even further. Therefore, the behaviour of Mg-2Ag in DMEM proved that testing in physiological conditions, in vitro leads to a less aggressive degradation process. Results from $\mathrm{Mg}$ $2 \mathrm{Ag}$ also indicate that a larger grain size also decreases the corrosion resistance of the $\mathrm{Mg}$ alloy (Liu et al., 2015).

In contrast, pure $\mathrm{Mg}$ and $\mathrm{Mg}-10 \mathrm{Gd}$ in disc shape showed a stable and slow degradation compared to Mg-2Ag (Fig. 2 and Table 3). These two alloys have a smaller grain size $(<22.3 \mu \mathrm{m})$ and a larger amount of Mn. According to literature, $\mathrm{Mn}$ forms intermetallic particles with $\mathrm{Fe}$, which are less favourable to promoting galvanic dissolution; thus, Mn increases the Fe tolerance limit (Lee et al., 2009; Reichek et al., 1985). Hence, Mn can reduce the negative influence of $\mathrm{Fe}$ on the corrosion behaviour, explaining the slower degradation behaviour of pure $\mathrm{Mg}$ and Mg-10Gd discs in vitro. The surface preparation of the discs facilitates the data interpretation since influencing parameter, such as impurities and oxidation at the sample surface, can be suppressed from the analysis. However, in a real application this preparation might not be possible.
There was a systematic difference between DRs calculated in vitro by gravimetry and by $\mathrm{H}_{2}$ generation (Table 3). The $\mathrm{H}_{2}$ evolution gave lower DR compared to the ML method. This difference can be explained by the particle undermining model (Song and Atrens, 1999), and perhaps the dissolution of hydrogen in the $\mathrm{Mg}$ sample (Atrens et al., 2015; Remennik et al., 2011; Zainal Abidin et al., 2013).

In order to stabilise the $\mathrm{pH}$ within the physiological range (between 7 and 8), the use of DMEM buffered with $\mathrm{CO}_{2}$ and $\mathrm{HCO}_{3}^{-}$and the application of UV-C radiation for sterilisation seemed appropriate. Moreover, it mimicked the natural human blood buffering system. This allowed the presence of $\mathrm{HCO}_{3}^{-}$, which is another important ion that promotes $(\mathrm{Mg}, \mathrm{Ca})-\mathrm{CO}_{3}$ formation at the surface layer. The stirring produced a dynamic flow making the sample and funnel an 'open' system avoiding a local $\mathrm{pH}$ increase inside the funnel, which falsifies the in vitro data, as other authors reported (Hofstetter et al., 2015b; Kirkland et al., 2012).

In summary, the PBS and HBSS with $\mathrm{Ca}^{2+}$ did not represent the degradation behaviour of $\mathrm{Mg}$ alloys in vivo because of the lack of relevant ions. This was indicated by the fast degradation of $\mathrm{Mg}-2 \mathrm{Ag}$ in PBS and HBSS, while its behaviour under near physiological conditions with DMEM and in animal experiments was rather stable.

\section{In vivo}

In degradation tests in vivo, the Mg-10Gd alloy, processed as a pin, had the highest DR in comparison to pure $\mathrm{Mg}$ and $\mathrm{Mg}-2 \mathrm{Ag}$ (Table 3). However, the number of gas pockets detected with $\mathrm{Mg}-10 \mathrm{Gd}$ was much lower than with pure $\mathrm{Mg}$ and $\mathrm{Mg}-2 \mathrm{Ag}$ (Fig. 3b). Many mechanisms can explain the lack of gas bubbles at the first stage of the degradation process of $\mathrm{Mg}$ implants. (i) Gas might not be trapped around the implant at this early healing stage. (ii) As Kuhlmann et al. reported, $\mathrm{H}_{2}$ can be exchanged very quickly after implantation through tissue and skin (Kuhlmann et al., 2013). (iii) Mg metal can store significant amounts of hydrogen (Nogita et al., 2009). Many authors use the dissolution of hydrogen in the $\mathrm{Mg}$ sample to explain the difference between the DRs calculated by hydrogen evolution and by ML (Atrens et al., 2015; Remennik et al., 2011; Zainal Abidin et al., 2013). (iv) Mg-RE alloys, e.g. $\mathrm{Mg}-10 \mathrm{Gd}$, can form hydrides in cuboid shape absorbing hydrogen from the environment (Gan et al., 2012; Marco et al., 2016; Peng et al., 2011). (v) Hydrogen might be incorporated in the degradation layer forming phosphate containing degradation products such as $(\mathrm{Mg}, \mathrm{Ca})-\mathrm{HPO}_{4}$ and $(\mathrm{Mg}, \mathrm{Ca})-\left(\mathrm{H}_{2} \mathrm{PO}_{4}\right)_{2}$. Only the mechanisms (iv) can explain the lack of gas cavities around implanted Mg$10 \mathrm{Gd}$ pins. Perhaps mechanism (i) could also explain it, although the same procedure was applied during all the implantations.

If we compared the DRs in vitro with those in vivo, we observed that Mg-10Gd pins in vivo showed the highest DR while Mg-10Gd discs in vitro had the lowest DR, together with pure $\mathrm{Mg}$ (Table 3). This could be due to the large amount of $\mathrm{Ni}$ and Fe detected in $\mathrm{Mg}-10 \mathrm{Gd}$ pins (20 and $158 \mathrm{ppm}$, respectively). In this case, the larger amount of $\mathrm{Ni}$ and Fe contained in this alloy as a pin shape 
indicated that the tolerance limits for these elements were exceeded, because $\mathrm{Ni}$ and $\mathrm{Fe}$ have the lowest tolerance limits (Hanawalt et al., 1942). These impurities could originate from the initial material, or be added to the $\mathrm{Mg}$ alloy by contact with steel tools which can contain $\mathrm{Fe}, \mathrm{Ni}$ and $\mathrm{Cr}$ as shown by the particle found on the surface in Fig. 7 c. Thus, the processing route can have a large impact on the degradation performance of the $\mathrm{Mg}$ alloy. Moreover, these results indicated that the larger amount of $\mathrm{Gd}$ in pin shape compared to discs did not seem to play an important role in reducing the negative influence of impurities.

Interestingly, $\mathrm{Mg}-2 \mathrm{Ag}$ discs in vitro also showed the opposite behaviour to Mg-2Ag pins in vivo (Table 3 ). The larger grain size of discs $(43.7 \mu \mathrm{m})$ versus pins $(25.7 \mu \mathrm{m})$ did seem to increase the degradation process. However, in contrast with what is known, the larger amount of $\mathrm{Fe}$ content in $\mathrm{Mg}-2 \mathrm{Ag}$ pins (357 ppm) compared to discs (50 ppm) did not seem to increase the DR. There is a slower fluid flow restricted by bone and therefore, smaller amount of $\mathrm{Cl}^{-}$ions in contact with the $\mathrm{Mg}-2 \mathrm{Ag}$ pins in vivo, which would accelerate the degradation process by the influence of $\mathrm{Ag}$ and $\mathrm{Cl}$. In contrast, a large $\mathrm{V} / \mathrm{S}$ ratio applied in vitro can explain the faster degradation of $\mathrm{Mg}-2 \mathrm{Ag}$ discs. In the literature, the use of a clinically relevant $\mathrm{V} / \mathrm{S}$ ratio is recommended (Yang and Zhang, 2009; Zhen et al., 2013). These degradation results from DMEM immersion in vitro tests and in vivo experiments (Table 3) are, especially in the case of $\mathrm{Mg}-2 \mathrm{Ag}$, in accordance with a previous study where $\mathrm{Mg}-2 \mathrm{Ag}$ shows the highest $\mathrm{DR}$ in in vitro conditions in DMEM with $10 \%$ of foetal bovine serum (FBS) (Myrissa et al., 2016).

In general, these materials behaved in a different way under in vivo as compared to in vitro conditions. Firstly, this could be explained by the larger amount of impurities of $\mathrm{Fe}, \mathrm{Ni}$ and $\mathrm{Cu}$ detected in the studied $\mathrm{Mg}$ pins as compared to discs. $\mathrm{Mg}-2 \mathrm{Ag}$ pins, for instance, had the greatest Fe content, which was due to a different processing with several more extrusion steps than pure $\mathrm{Mg}$ and $\mathrm{Mg}-10 \mathrm{Gd}$ pins. Moreover, the in vivo and in vitro tests applied, different conditions and many factors such as ion concentration, $\mathrm{pH}$ level or blood flow as well as protein and different kinds of cells can affect the DR of the materials (Martinez-Sanchez et al., 2015; Mueller et al., 2007; Poinern et al., 2012; Shadanbaz et al., 2014; Walker et al., 2012; Witte et al., 2006; Xue et al., 2012; Yang et al., 2012; Zainal Abidin et al., 2013). Gas pockets were observed in vivo, which does not mean that bone is unable to heal completely - even if the resorption is too rapid and bubbles are large (Kraus et al., 2012). In addition, the lack of surface preparation of the pins before implantation might have an influence since the oxide film can slow down the degradation process while the impurities might accelerate it. Although, the influence of the oxide layer is considered to be moderate, the complexity of the data interpretation does not increase in the case of neither polished nor ground pins.

\section{Degradation mechanisms}

In these short term studies the degradation mechanisms observed depended on the environment where the $\mathrm{Mg}$ sample was exposed. In general, under any testing condition, the $\mathrm{Mg}$ sample started degrading according to the following well-known anodic and cathodic reactions (equations 4 and 5, respectively).

$$
\mathrm{Mg} \rightarrow \mathrm{Mg}^{2+}+2 \mathrm{e}^{-}
$$

$$
2 \mathrm{H}_{2} \mathrm{O}+2 \mathrm{e}^{-} \rightarrow 2 \mathrm{OH}^{-}+\mathrm{H}_{2}
$$

As explained above, a specific degradation layer was generated depending on the sample and the testing conditions applied to the Mg surface. Therefore, the degradation mode and the mechanisms depended on the degradation layer performance. During in vivo and in vitro tests with DMEM, homogeneous corrosion was observed on the studied $\mathrm{Mg}$ samples. Under these conditions, the degradation layer was formed by $\mathrm{Ca}$ and $\mathrm{P}$ rich layers separately from $\mathrm{Mg}(\mathrm{OH})_{2}$ and $(\mathrm{Mg}, \mathrm{Ca})-\mathrm{CO}_{3}$. Therefore, these layers formed a more stable separation between the implant surface and the environment. This was also observed in DMEM in our previous work (Marco et al., 2016). A homogeneous degradation was also observed in PBS and HBSS with pure $\mathrm{Mg}$ and $\mathrm{Mg}-10 \mathrm{Gd} . \mathrm{Mg}-2 \mathrm{Ag}$, for instance, showed localised and pitting corrosion in PBS and HBSS due to the higher $\mathrm{Cl}^{-}$content and the presence of $\mathrm{Ag}$ in the alloy. Hence, the degradation layer formed by $\mathrm{Mg}(\mathrm{OH})_{2}$ and $\mathrm{Mg}_{-} \mathrm{PO}_{4}$ did not protect the $\mathrm{Mg}$ surface in media with higher $\mathrm{Cl}^{-}$ion content $(>140 \mathrm{mM})$.

Other mechanisms, such as particle undermining (Song and Atrens, 1999), could not be observed due to the short duration of these studies, although it was probably one of the factors influencing the lower DR calculated by hydrogen evolution as compared to the mass loss method. However, the influence of different impurity contents and oxidation of $\mathrm{Mg}$ surface still needs to be studied in a more systematic manner.

\section{Conclusions}

In vitro and in vivo degradation behaviour of several alloys was compared after $7 \mathrm{~d}$. The degradation layer has been characterised in order to compare results from lab and animal studies. The results attested to the following:

The physiological testing set-up applied in this study, with DMEM as electrolyte, could not only maintain a physiological $\mathrm{pH}$ level, but also the degradation layer formed in vivo on several $\mathrm{Mg}$ alloys providing comparable DRs. These rates, especially for $\mathrm{Mg}-2 \mathrm{Ag}$ were lower in DMEM and in vivo than in PBS and HBSS. This indicates that in vivo, as well as in vitro under near physiological conditions, there were more moderate testing conditions that did not promote the $\mathrm{Mg}$ degradation process. The lower $\mathrm{Cl}^{-}$ion concentration and the presence of $\mathrm{Ca}^{2+}, \mathrm{PO}_{4}^{3-}$ and $\mathrm{HCO}_{3}^{-}$ions highly influenced the degradation process of the studied $\mathrm{Mg}$ alloys and their consequent degradation layer formation. Hence, PBS and HBSS did not closely represent the degradation behaviour in vivo, because the degradation layer differed from what was found in vivo.

The same $\mathrm{Mg}$ alloy from another manufacturing process led to a different impurity content and microstructure, 
which seemed to drive the degradation performance downplaying the role of alloying additions, such as Gd and Ag. The importance of impurity and grain size control during the processing was thereby highlighted. The control of elements such as $\mathrm{Fe}$ and $\mathrm{Ni}$, which have a low tolerance limit, must be reduced (to levels lower than $50 \mathrm{ppm}$ and $10 \mathrm{ppm}$, respectively), but others, e.g. Mn, can be desirable when the purity is low.

The initial surface can contain impurity particles with $\mathrm{Fe}, \mathrm{Cu}$ or $\mathrm{Ni}$ and an oxide layer as a result of the production process and the storage of the $\mathrm{Mg}$ implant. Therefore, a surface preparation was found recommendable in any $\mathrm{Mg}$ degradation study in order to facilitate data interpretation.

The elemental mapping revealed that hydroxyapatite in bone had higher $\mathrm{Ca}$ and $\mathrm{P}$ levels than the $\mathrm{Ca}-\mathrm{P}$ rich degradation layer formed in vivo. Thus, these different calcium orthophosphate structures could help to distinguish bone from the degradation layer formed on the implant surface by elemental mapping.

\section{Acknowledgements}

This research is supported by the PEOPLE Programme (Marie Skłodowska-Curie Actions) of the European Union's Seventh Framework Programme FP7/2007-2013/ under REA grant agreement $\mathrm{n}^{\circ} 289163$. The authors also want to thank Gábor Szakács for all the work done in the material production, Johannes Eichler for the valuable help during the surgery and Claudia Kleinhans for the technical support. Furthermore, the authors appreciate the support of Prof. Ute Schäfer and they would like to thank the Institute of Biomedical Research at the Medical University of Graz for providing the infrastructure facilities to perform the animal studies.

We wish to confirm that there are no known conflicts of interest associated with this publication and there has been no significant financial support for this work that could have influenced its outcome.

\section{References}

Agha NA, Feyerabend F, Mihailova B, Heidrich S, Bismayer U, Willumeit-Römer R (2016) Magnesium degradation influenced by buffering salts in concentrations typical of in vitro and in vivo models. Mater Sci Eng C Mater Biol Appl 58: 817-825.

Ahmadkhaniha D, Fedel M, Heydarzadeh Sohi M, Zarei Hanzaki A, Deflorian F (2016) Corrosion behavior of magnesium and magnesium-hydroxyapatite composite fabricated by friction stir processing in Dulbecco's phosphate buffered saline. Corros Sci 104: 319-329.

Alvarez-Lopez M, Pereda MD, del Valle JA, FernandezLorenzo M, Garcia-Alonso MC, Ruano OA, Escudero ML (2010) Corrosion behaviour of AZ31 magnesium alloy with different grain sizes in simulated biological fluids. Acta Biomater 6: 1763-1771.

Atrens A, Song GL, Liu M, Shi Z, Cao F, Dargusch MS (2015) Review of recent developments in the field of magnesium corrosion. Adv Eng Mater 17: 400-453.
Bracht K, Angrisani N, Seitz JM, Eifler R, Weizbauer A, Reifenrath J (2015) The influence of storage and heat treatment on a magnesium-based implant material: an in vitro and in vivo study. Biomed Eng Online 14: 92.

Feyerabend F, Druecker H, Laipple D, Vogt C, Stekker M, Hort N, Willumeit R (2012) Ion release from magnesium materials in physiological solutions under different oxygen tensions. J Mate Sci Mater Med 23: 9-24.

Feyerabend F, Wendel HP, Mihailova B, Heidrich S, Agha NA, Bismayer U, Willumeit-Römer R (2015) Blood compatibility of magnesium and its alloys. Acta Biomater 25: 384-394.

Fischerauer SF, Kraus T, Wu X, Tangl S, Sorantin E, Hänzi AC, Löffler JF, Uggowitzer PJ, Weinberg AM (2013) In vivo degradation performance of micro-arc-oxidized magnesium implants: a micro-CT study in rats. Acta Biomater 9: 5411-5420.

Friedrich HE, Mordike BL (2006) Magnesium technology. Springer-Verlag, Berlin: 470-481.

Galli S, Hammel JU, Herzen J, Szakács G, Lukáč F, Vlček M, Marco I, Wennerberg AM, Willumeit-Römer R, Jimbo R (2015) Corrosion behaviour of 3 Mg-alloys in bone: a high-resolution investigation. Eur Cell Mater 30 Supp 3: 93.

Gan W, Huang Y, Yang L, Kainer KU, Jiang M, Brokmeier HG, Hort N (2012) Identification of unexpected hydrides in Mg-20 wt\% Dy alloy by high-brilliance synchrotron radiation. J Appl Cryst 45: 17-21.

Hanawalt J, Nelson C, Peloubet J (1942) Corrosion studies of magnesium and its alloys. AIME 147: 273-299.

Hofstetter J, Martinelli E, Pogatscher S, Schmutz P, Povoden-Karadeniz E, Weinberg AM, Uggowitzer PJ, Löffler JF, (2015a) Influence of trace impurities on the in vitro and in vivo degradation of biodegradable $\mathrm{Mg}-5 \mathrm{Zn}$ 03Ca alloys. Acta Biomater 23: 347-353.

Hofstetter J, Martinelli E, Weinberg AM, Becker M, Mingler B, Uggowitzer PJ, Löffler JF (2015b) Assessing the degradation performance of ultrahigh-purity magnesium in vitro and in vivo. Corros Sci 91: 29-36.

Hort N, Huang Y, Fechner D, Stoermer M, Blawert C, Witte F, Vogt C, Druecker H, Willumeit R, Kainer KU, Feyerabend F (2010) Magnesium alloys as implant materials - principles of property design for Mg-RE alloys. Acta Biomater 6: 1714-1725.

Kirkland NT, Birbilis N, Staiger MP (2012) Assessing the corrosion of biodegradable magnesium implants: a critical review of current methodologies and their limitations. Acta Biomater 8: 925-936.

Kirkland NT, Lespagnol J, Birbilis N, Staiger MP (2010) A survey of bio-corrosion rates of magnesium alloys. Corros Sci 52: 287-291.

Kraus T, Fischerauer SF, Hänzi AC, Uggowitzer PJ, Löffler JF, Weinberg AM (2012) Magnesium alloys for temporary implants in osteosynthesis: In vivo studies of their degradation and interaction with bone. Acta Biomater 8: $1230-1238$.

Kubasek J, Vojtech D (2013) Structural and corrosion characterisation of biodegradable $\mathrm{Mg}-\mathrm{RE}(\mathrm{RE}=\mathrm{Gd}, \mathrm{Y}, \mathrm{Nd})$ alloys. Trans Nonferrous Met Soc China 23: 1215-1225.

Kuhlmann J, Bartsch I, Willbold E, Schuchardt S, Holz O, Hort N, Höche D, Heineman, WR, Witte F (2013) Fast 
escape of hydrogen from gas cavities around corroding magnesium implants. Acta Biomater 9: 8714-8721.

Kuwahara H, Al-Abdullat Y, Mazaki N, Tsutsumi S, Aisawa T (2001) Precipitation of magnesium apatite on pure magnesium surface during immersing in Hank's solution. Mater Trans 42: 1317-1321.

Lee JY, Han G, Kim YC, Byun JY, Jang JI, Seok HK, Yang SJ (2009) Effects of impurities on the biodegradation behavior of pure magnesium. Met Mater Int 15: 955-961.

Li H, Zheng Y, Qin L (2014) Progress of biodegradable metals Prog Nat Sci 24: 414-422.

Li Y, Wen C, Mushahary D, Sravanthi R, Harishankar N, Pande G, Hodgson P (2012) Mg-Zr-Sr alloys as biodegradable implant materials. Acta Biomater 8: 3177 3188 .

Li Z, Gu X, Lou S, Zheng Y (2008) The development of binary $\mathrm{Mg}-\mathrm{Ca}$ alloys for use as biodegradable materials within bone. Biomaterials 29: 1329-1344.

Liu M, Uggowitzer PJ, Nagasekhar AV, Schmutz P, Easton M, Song GL, Atrens A (2009) Calculated phase diagrams and the corrosion of die-cast $\mathrm{Mg}-\mathrm{Al}$ alloys. Corros Sci 51: 602-619.

Liu Y, Liu D, You C, Chen M (2015) Effects of grain size on the corrosion resistance of pure magnesium by cooling rate-controlled solidification. Front Mater Sci 9: 247-253.

Marco I, Feyerabend F, Willumeit-Römer R, Van der Biest O (2016) Degradation testing of Mg alloys in Dulbecco's modified eagle medium: influence of medium sterilisation. Mater Sci Eng C Mater Biol Appl: 62: 68-78.

Martinez-Sanchez AH, Luthringer BJC, Feyerabend F, Willumeit R (2015) Mg and Mg alloys: how comparable are in vitro and in vivo corrosion rates? A review. Acta Biomater 13: 16-31.

Mercer WE, Hillis JE (1992) The critical contaminant limits and salt water corrosion performance of magnesium AE42 Alloy. SAE, Detroit: 1-10.

Mueller WD, Fernandez-Lorenzo M, Nascimento ML, Zeddies M (2009) Degradation of magnesium and its alloys: dependence on the composition of the synthetic biological media. J Biomed Mater Res A 90: 487-495.

Mueller WD, Nascimento ML, Zeddies M, Córsico M, Gassa LM, Fernandez Lorenzo de Mele M (2007) Magnesium and its alloys as degradable biomaterials: corrosion studies using potentiodynamic and EIS electrochemical techniques. Mater Res 10: 5-10.

Myrissa A, Agha NA, Lu Y, Martinelli E, Eichler J, Szakács G, Kleinhans C, Willumeit-Römer R, Schäfer U, Weinberg AM (2016) In vitro and in vivo comparison of binary $\mathrm{Mg}$ alloys and pure $\mathrm{Mg}$. Mater Sci Eng C Mater Biol Appl 61: 865-874.

Nogita K, Ockert S, Pierce J, Greaves MC, Gourlay CM, Dahle AK (2009) Engineering the $\mathrm{Mg}-\mathrm{Mg}_{2} \mathrm{Ni}$ eutectic transformation to produce improved hydrogen storage alloys. Int J Hydrogen Energy 34: 7686-7691.

Peng Q, Huang Y, Meng J, Li Y, Kainer KU (2011) Strain induced $\mathrm{GdH}_{2}$ precipitate in $\mathrm{Mg}-\mathrm{Gd}$ based alloys. Intermetallics 19: 382-389.

Poinern GEJ, Brundavanam S, Fawcett D (2012) Biomedical magnesium alloys: a review of material properties, surface modifications and potential as a biodegradable orthopaedic implant. Am J Biomed Eng 2: 218-240.

Reichek KN, Clark KJ, Hillis JE (1985) Controlling the salt water corrosion performance of magnesium AZ91 alloy. SAE transactions 94: 318-329 doi:10.4271/850417.

Remennik S, Bartsch I, Willbold E, Witte F, Shechtman D (2011) New, fast corroding high ductility $\mathrm{Mg}-\mathrm{Bi}-\mathrm{Ca}$ and $\mathrm{Mg}-\mathrm{Bi}-\mathrm{Si}$ alloys, with no clinically observable gas formation in bone implants. Mater Sci Eng B Solid State Mater Adv Technol 176: 1653-1659.

Robinson DA, Griffith RW, Shechtman D, Evans RB, Conzemius MG (2010) In vitro antibacterial properties of magnesium metal against Escherichia coli, Pseudomonas aeruginosa and Staphylococcus aureus. Acta Biomater 6: 1869-1877.

Schille C, Braun M, Wendel HP, Scheideler L, Hort N, Reichel HP, Schweizer E, Geis-Gerstorfer J (2011) Corrosion of experimental magnesium alloys in blood and PBS: a gravimetric and microscopic evaluation. Mater Sci Eng B Solid State Mater Adv Technol 176: 1797-1801.

Schinhammer M, Hofstetter J, Wegmann C, Moszner F, Loeffler JF, Uggowitzer PJ (2013) On the immersion testing of degradable implant materials in simulated body fluid: active $\mathrm{pH}$ regulation using $\mathrm{CO}_{2}$. Adv Eng Mater 15: 434-441.

Shadanbaz S, Walker J, Woodfield TB, Staiger MP, Dias GJ (2014) Monetite and brushite coated magnesium: in vivo and in vitro models for degradation analysis $\mathrm{J}$ Mater Sci Mater Med 25: 173-183.

Song GL, Atrens A, (1999) Corrosion mechanisms of magnesium alloys. Adv Eng Mater 1: 11-33.

Staiger MP, Pietak AM, Huadmai J, Dias G (2006) Magnesium and its alloys as orthopedic biomaterials: a review. Biomaterials 27: 1728-1734.

Tie D, Feyerabend F, Hort N, Willumeit R, Hoeche D (2010) XPS studies of magnesium surfaces after exposure to Dulbecco's modified eagle medium, Hank's buffered salt solution, and simulated body fluid. Adv Eng Mater 12: 699-704.

Tie D, Feyerabend F, Mueller WD, Schade R, Liefeith K, Kainer KU, Willumeit R (2013) Antibacterial biodegradable Mg-Ag alloys. Eur Cell Mater 25: 284-298.

Trinidad J, Arruebarrena G, Marco I, Hurtado I, Saenz de Argandoña E (2013) Effectivity of fluoride treatment on hydrogen and corrosion product generation in temporal implants for different magnesium alloys. Proc Inst Mech Eng H 227: 1301-1311.

Walker J, Shadanbaz S, Kirkland NT, Stace E, Woodfield T, Staiger MP, Dias GJ (2012) Magnesium alloys: predicting in vivo corrosion with in vitro immersion testing. J Biomed Mater Res B Appl Biomater 100: 11341141.

Wang H, Estrin Y, Zúberová Z (2008) Bio-corrosion of a magnesium alloy with different processing histories. Mater Lett 62: 2476-2479.

Willumeit R, Fischer J, Feyerabend F, Hort N, Bismayer U, Heidrich S, Mihailova B (2011) Chemical surface alteration of biodegradable magnesium exposed to corrosion media. Acta Biomater 7: 2704-2715. 
Witte F, Fischer J, Nellesen J, Crostack HA, Kaese V, Pisch A, Beckmann F, Windhagen H (2006) In vitro and in vivo corrosion measurements of magnesium alloys. Biomaterials 27, 1013-1018.

Witte F, Kaese V, Haferkamp H, Switzer E, MeyerLindenberg A, Wirth CJ, Windhagen H (2005) In vivo corrosion of four magnesium alloys and the associated bone response. Biomaterials 26: 287-291.

Xu L, Yu G, Zhang E, Pan F, Yang K (2007) In vivo corrosion behavior of $\mathrm{Mg}-\mathrm{Mn}-\mathrm{Zn}$ alloy for bone implant application. J Biomed Mater Res A 83: 703-711.

Xue D, Yun Y, Tan Z, Dong Z, Schulz MJ (2012) In vivo and in vitro degradation behavior of magnesium alloys as biomaterials. J Mater Sci Techn 28: 261-267.

Yang L, Hort N, Willumeit R, Feyerabend F, (2012) Effects of corrosion environment and proteins on magnesium corrosion. Corros Eng Sci Techn 47: 335-339.

Yang L, Zhang E (2009) Biocorrosion behavior of magnesium alloy in different simulated fluids for biomedical application. Mater Sci Eng C Mater Biol Appl 29: 1691-1696.

Yang L, Zhou X, Liang SM, Schmid-Fetzer R, Fan Z, Scamans G, Robson J, Thompson G (2015) Effect of traces of silicon on the formation of Fe-rich particles in pure magnesium and the corrosion susceptibility of magnesium. J Alloys Compd 619: 396-400.

Zainal Abidin NI, Martin D, Atrens A (2011) Corrosion of high purity Mg, AZ91, ZE41 and Mg-2Zn-02Mn in Hank's solution at room temperature. Corros Sci 53: 862872.

Zainal Abidin NI, Rolfe B, Owen H, Malisano J, Martin D, Hofstetter J, Uggowitzer PJ, Atrens A (2013) The in vivo and in vitro corrosion of high-purity magnesium and magnesium alloys WZ21 and AZ91. Corros Sci 75: 354366.

Zhang LN, Hou ZT, Ye X, Xu ZB, Bai XL, Shang P (2013) The effect of selected alloying element additions on properties of $\mathrm{Mg}$-based alloy as bioimplants: a literature review. Front. Mater. Sci. 7: 227-236.

Zhang S, Li J, Song Y, Zhao C, Zhang X, Xie C, Zhang Y, Tao H, He Y, Jiang Y, Bian Y (2009) In vitro degradation, hemolysis and MC3T3-E1 cell adhesion of biodegradable Mg-Zn alloy. Mater Sci Eng C Mater Biol Appl 29: $1907-$ 1912.

Zhen Z, Xi TF, Zheng YF (2013) A review on in vitro corrosion performance test of biodegradable metallic materials. Trans Nonferrous Met Soc China 23: 2283-2293.

Zhu L, Wan P, Duan J, Tan L, Yang K (2014) An alternative magnesium-based root canal disinfectant: preliminary study of its efficacy against Enterococcus faecalis and Candida albicans in vitro. Prog Nat Sci 24: 441-445.

Zong Y, Yuan G, Zhang X, Mao L, Niu J, Ding W (2012) Comparison of biodegradable behaviors of AZ31 and Mg$\mathrm{Nd}-\mathrm{Zn}-\mathrm{Zr}$ alloys in Hank's physiological solution. Mater Sci Eng B Solid State Mater Adv Technol 177: 395-401.

Editor's note: There were no questions from reviewers for this paper, therefore there is no discussion with reviewers section.

Editor's note: The Scientific Editor responsible for this paper was Joost de Bruijn. 